\title{
West-Central African Diversity from the Stone Age to the Iron Age, Continuities and Transitions during the Late Pleistocene and the Holocene
}

\author{
Bernard Clist
}

No matter which site is studied and regardless of its age, archaeology should be concerned only with the search for man and his behavior. This will demand careful excavations of living sites, which should be well chosen. Excavation techniques should be such as to record maximum observation in the field, and in the laboratory the most recent techniques should be used. VAN NOTEN 1982: 13

Nearly forty years later, sadly we are still lacking the most basic chrono-cultural sequences in most parts of Central Africa, and 'the search of man and his behavior' is still wishful thinking. Of course, one of the important explanations (though not the only one) is the fragile political and social situation inhibiting research.

Nevertheless, archaeological research shows evidence for multiple, complex material cultures, suggesting various levels of human admixtures before the start of the Holocene (about 12,00o years ago). Though the picture we present here is based on research of heterogeneous quality and irregular geographical coverage in a vast area (roughly equivalent to the 27 countries of the European Union), a general pattern can still be outlined and of use as a benchmark for modern genetic research. Figure 3.1 locates the sectors with better Neolithic and Iron Age pottery sequences, and the four circled in black have a full sequence, starting from the Neolithic: 1), Corisco Island in Equatorial Guinea (Figure $\left.\left.3.1, \mathrm{n}^{\circ} 3\right) ; 2\right)$, northwest Gabon $\left(\mathrm{n}^{\circ} 4\right)$; 3 ), the Inner Congo Basin $\left(\mathrm{n}^{\circ} 9\right)$; and 4), the Upemba depression in the DRC $\left(\mathrm{n}^{\circ} 10\right)$.

Unfortunately, the archaeological cultures cannot be easily associated with languages or human groups:

... from a methodological standpoint, Bantu is a linguistic term, while a mute archaeological artefact is not Bantu. DE MARET 1989: 129 


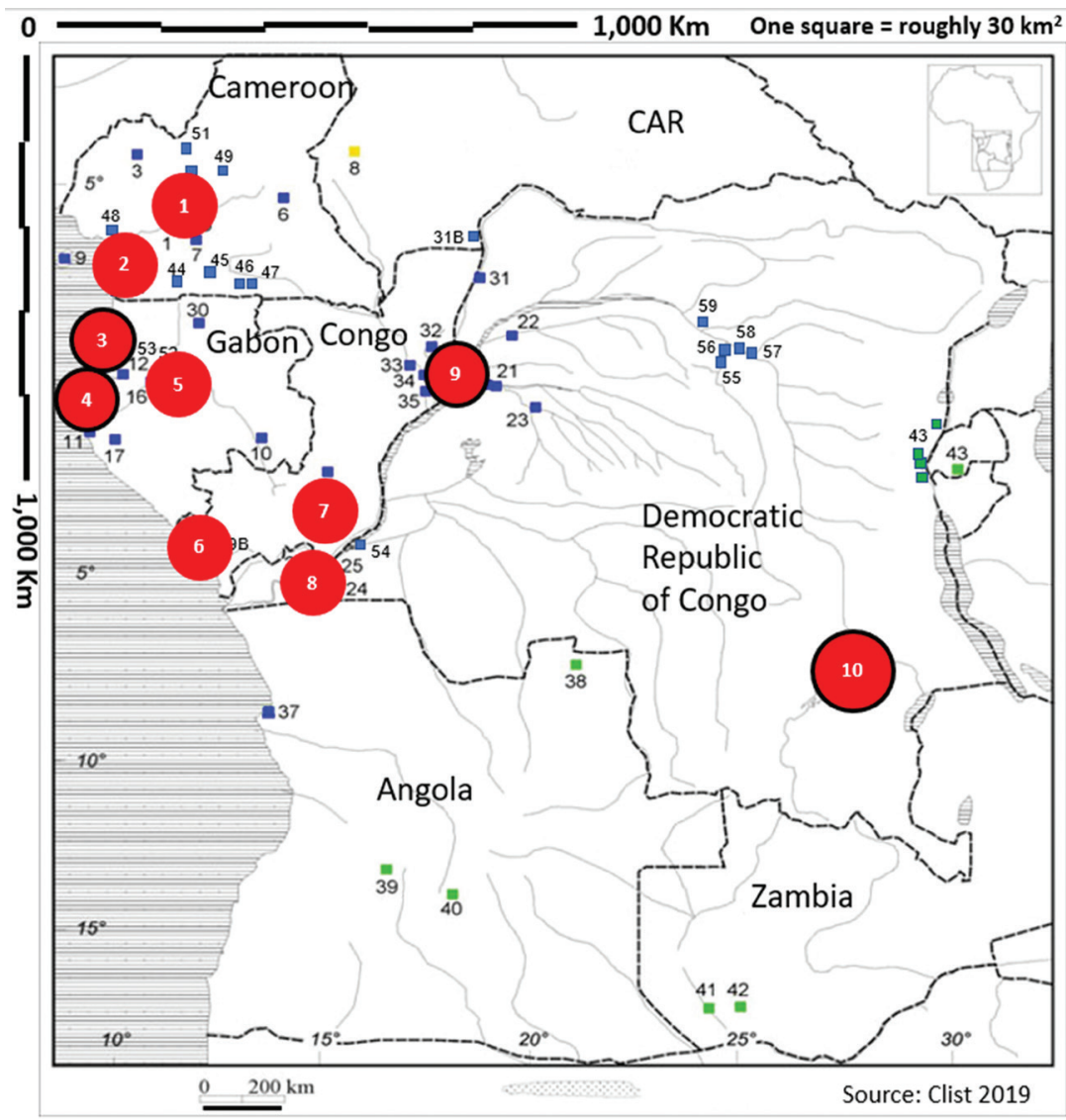

FIGURE 3.1 The better Iron Age cultural sequences in Central Africa. 1: Yaoundé area, Cameroon, 2: Coastal area, Cameroon, 3: Corisco island, Equatorial Guinea, 4: Libreville area, Gabon, 5: Middle Ogooué area, Gabon, 6: Coastal area, Congo, 7: Bateke plateaux, Congo, 8: Kongo Central province, DRC, 9: Inner Congo Basin, DRC, 10: Upemba depression, DRC. Circled in black, the only 4 complete sequences known today. Blue squares are some of the villages dated before and around 2,00о BP

FIGURE BY B. CLIST

Central Africa includes eight countries: Cameroon; Central African Republic (CAR); Sao Tomé and Principe; Equatorial Guinea; Gabon; Congo; Democratic Republic of Congo (DRC); and Angola (Figure 3.1). If we consider only the major fluvial basins in between plateaus and high ranges to the north, east and south (Lanfranchi \& Schwartz 1990: 5-67; Lanfranchi \& Clist 1991: 5-54), we can exclude northern Cameroon and northern CAR (associated with the Sahel region), southern Angola south of Lobito, and Zambia (oriented towards southern Africa). Different types of forests cover the landscape, with wooded 


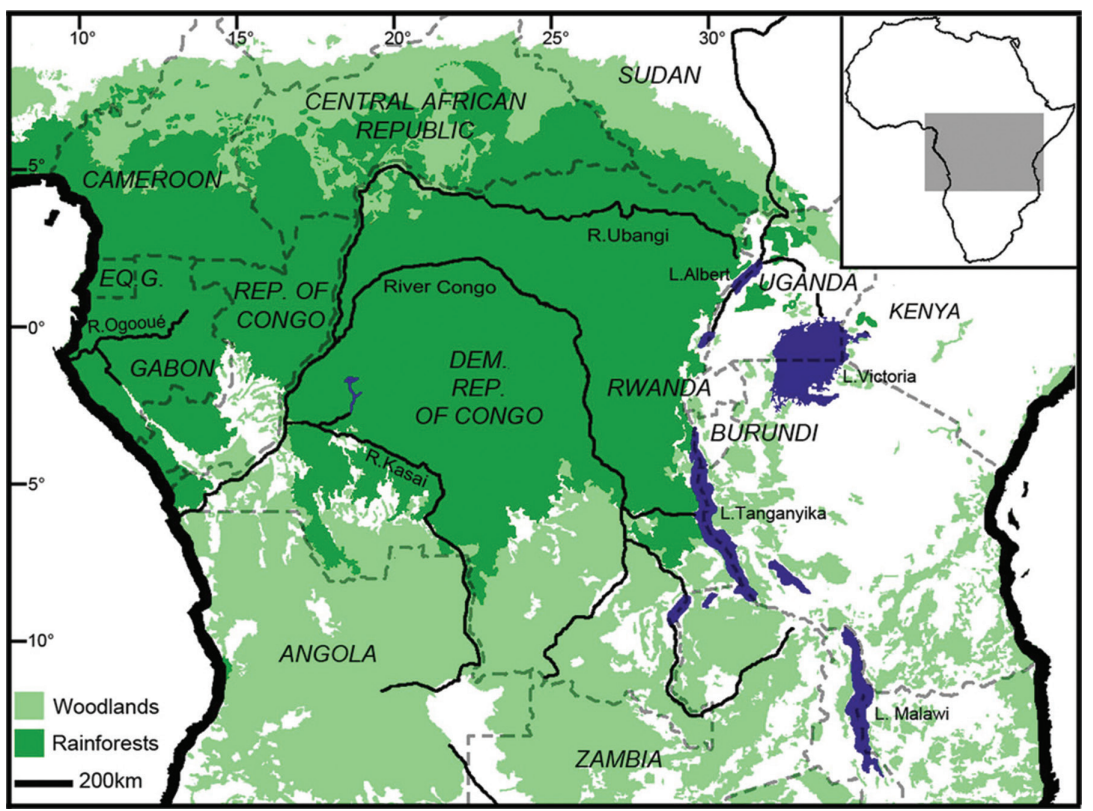

FIGURE 3.2 Rainforests and woodlands modern extension in Central Africa, white areas are savannas

FIGURE FROM TAYLOR 2016, FIG.15.1

savannas and woodlands extending to the north and south around the Congo and Ogooué River basins (Figure 3.2).

\section{$2 \quad$ Climatic Changes}

According to paleo-environmental data, dry climate periods with open savanna-like vegetation alternated with a warmer, humid climate and more forested vegetation during the Late Pleistocene and the following Holocene. Research at Bambili Lake in Cameroon (Lézine et al., 2019), supported by long-term pollen profiles onshore and offshore in Cameroon and offshore in Angola (Dupont et al., 2008, Lébamba et al., 2012, Lézine \& Cazet 2005, Maley \& Brenac 1998), document these changes. The Bambili evidence shows the

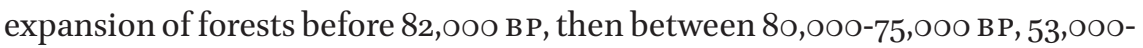

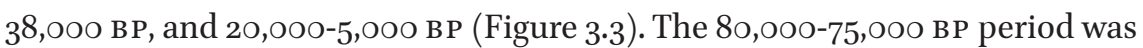
of similar amplitude as at the Pleistocene-Holocene boundary (c. 12, ооо ВР), both with higher tree-pollen counts than today. The well-known 'Stone Lines' were formed during the transition from dry to humid periods: increasing rainfall on savanna or wooded savanna let heavier components ('stone') move down-slope to form concentrations ('lines'). Sangoan and Lupemban tools are 


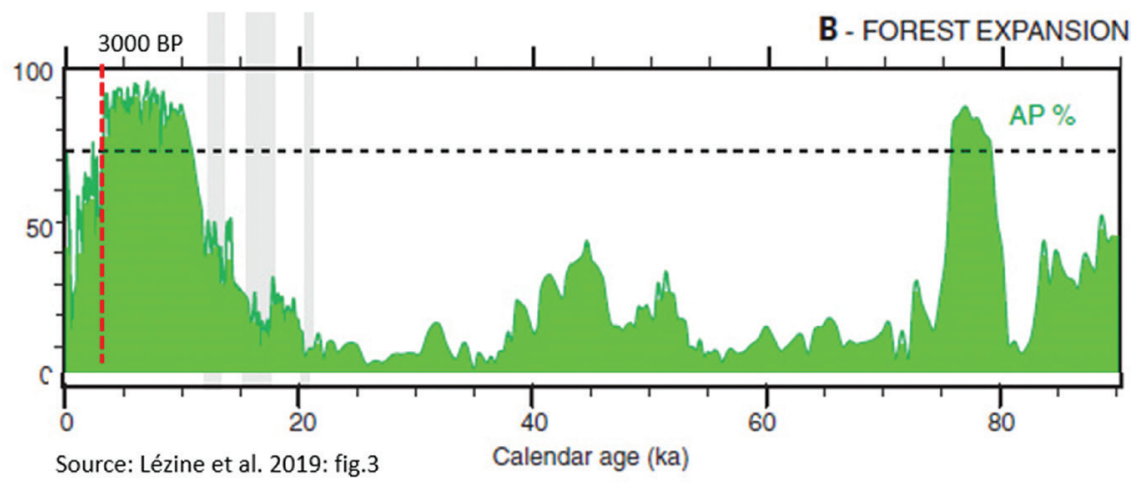

FIGURE 3.3 Palaeoenvironmental sequence of 9o,ooo years from Bambili lake, Cameroon. The tree pollen is illustrated in green, the other pollen in white. The black horizontal dotted line represents the modern level of the tree pollen. The vertical dotted red line marks the arrival of the first pottery using villages in the Cameroon/Gabon area circa 3,00о B P FIGURE FROM LÉZINE ET AL., 2019, FIG.3, ADAPTATION BY B. CLIST

found in or on the stone-lines (e.g. Bayle des Hermens et al., 1987; Mercader et al., 2002).

A severe transition separates the Pleistocene from the Holocene, characterized by mountain forests expanding (starting around 20,00о BP, Figure 3.3), and the Atlantic Ocean rising enough to submerge coastal Stone Age sites. This humid climate persisted until c. 3,Ооо ВР when savannas spread due to a severe dry period, known as the Late Holocene Forest Crisis (LHFC), ending around 2, ооо в Р (Maley et al., 2018). The mechanism of this major vegetation change is felt earlier, с. 5, Ооо вP, with the slow lowering of the Sinnda and Kitina lakes in Congo (Schwartz et al., 2000). It is around the start of the LHFC that several waves of low-density stone and pottery using villagers inhabited the west, but the first movements southwards from Cameroon happened before the forest regression. Other groups of people, this time iron-using and/or metallurgists (de Maret 2013), followed several centuries later.

We need more local studies to establish the way local climate and vegetation changed following the trend we have outlined. From the available data about the LHFC, vast expanses of savanna developed (Maley 1987; Schwartz 1991), creating a $400 \mathrm{~km}$ wide Sangha River Interval (SRI), a corridor that enabled Early Iron Age (EIA) peoples and Bantu-speakers (Bostoen et al., 2015, Grollemund et al., 2015) to expand more easily through the region's dense vegetation (Schwartz 1992). Other data, however, show that forests persisted in this corridor (Brncic et al., 2007, 2009, Kiahtipes 2016; Brémond et al., 2017; Tovar et al., 2019). A recent reassessment concluded the SRI was covered by forests (Giresse et al., 2020). Archaeological evidence does not show any settlement 
in the SRI before 2,O2O в P for the Pikunda-Munda Group (Seidensticker 2016) or before 2,13о вр to the north (Morin-Rivat et al., 2014), while on the western fringe of the SRI no settlement existed before c. 2,260 BP (Morin-Rivat et al., 2014, 2016). This re-evaluation strengthens our modelling of the EIA and illustrates a large-scale movement of various peoples between about 2,200 and 2,00о вP from Cameroon to the DRC, mainly through the forests, and without using the SRI as it was stated a few years ago (see below).

Figure 3.3 illustrates the speed of vegetation changes for humans who had to adapt accordingly to the new climatic conditions, the changing position and availability of the animals they were hunting, and the fruit trees and tubers they were collecting. We can suggest that climate-induced movements of hunter-gatherer groups sometimes led to their physical interaction.

Local palaeoenvironemental sequences must also reach into the EIA and the Late Iron Age (LIA). Several short-term studies with a high resolution already exist (e.g. Ngomanda et al., 2005, 2007; Brnic et al., 2009). We have to determine if the 'Medieval Warm Period' (or 'Medieval Climate Optimum') of AD 950 to 1250 and the colder 'Little Ice Age' of AD 1270 to 1850 impacted human societies through increasing or decreasing food production yields. Perhaps the 'Little Ice Age' contributed to the rise of kingdoms on the southern edge of the rainforests as a response to agricultural stress, as illustrated by the drop in rainfall between AD 1400 and 1700 recorded at Kamalete Lake in Gabon (Ngomanda et al., 2005). Potential reactions of a society facing an ecological or economic crisis are, amongst several, changes in social organization.

\section{3}

\section{Hunter-Gatherers}

The succession of an Early, Middle, and Later Stone Age was long considered as being chronological markers through the Pleistocene and Holocene, following a simple evolutionist perspective. Chronology went hand in hand with technological development, from the pre-Acheulean to the Later Stone Age (LSA). Since the 1980s, we acknowledge the complex reality and differences in stone industries.

The Middle Stone Age (MSA) is characterized by tools struck from carefully prepared Levallois cores, dated from 300,о०о вР (Taylor 2014). It witnessed the co-occurrence of diverse lithic reduction strategies, including bifacial prepared core technique, blade and backed blade technologies (Cornelissen 2016; Taylor 2016; Lanfranchi and Clist 1991: 55-95), and ending with a major size reduction to microlithic assemblages in the Holocene (see Lanfranchi and Clist 1991: 97-132). We now know that LSA assemblages co-existed alongside 
MSA assemblages before 30,000 BP (e.g. Matupi cave in the DRC and Shum Laka rock shelter in Cameroon; Cornelissen 2016 and our Figure 3.4).

While in some parts of Central Africa, it is only with the Pleistocene/ Holocene climate transition we witness a transformation of tool kits, from bifacial to microlithic components, in other areas microlithic industries existed throughout the MSA (Cornelissen 1997). People used several "chaînes opératoires", or production sequences, to create various tool-kits, suggesting

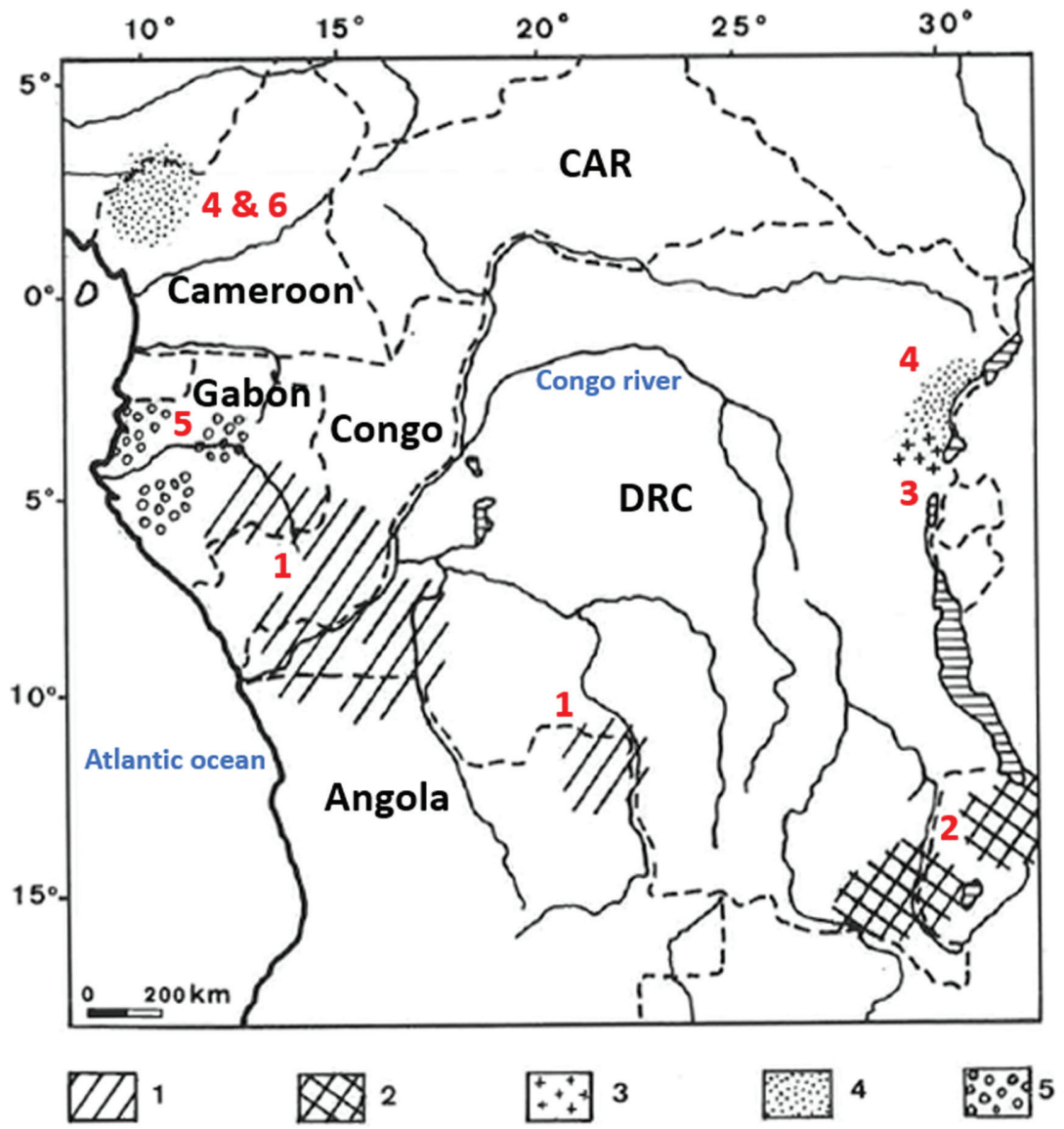

FIGURE 3.4 Spatial extension of the known stone industries from West-Central Africa. 1: Bifacial tradition of the Sangoan, Lupemban, and Tshitolean industries, 2: Middle Stone Age occupations with, and Holocene microlithic industries without bifacially flaked implements, 3: Middle Stone Age occupations without bifacially flaked implements, 4 : Pre-Holocene microlithic industries, 5: Holocene microlithic industries without a bifacial component, 6: Holocene microlithic industries FIGURE BASED ON CORNELISSEN 1997, FIG. 30, ADAPTED BY B. CLIST 


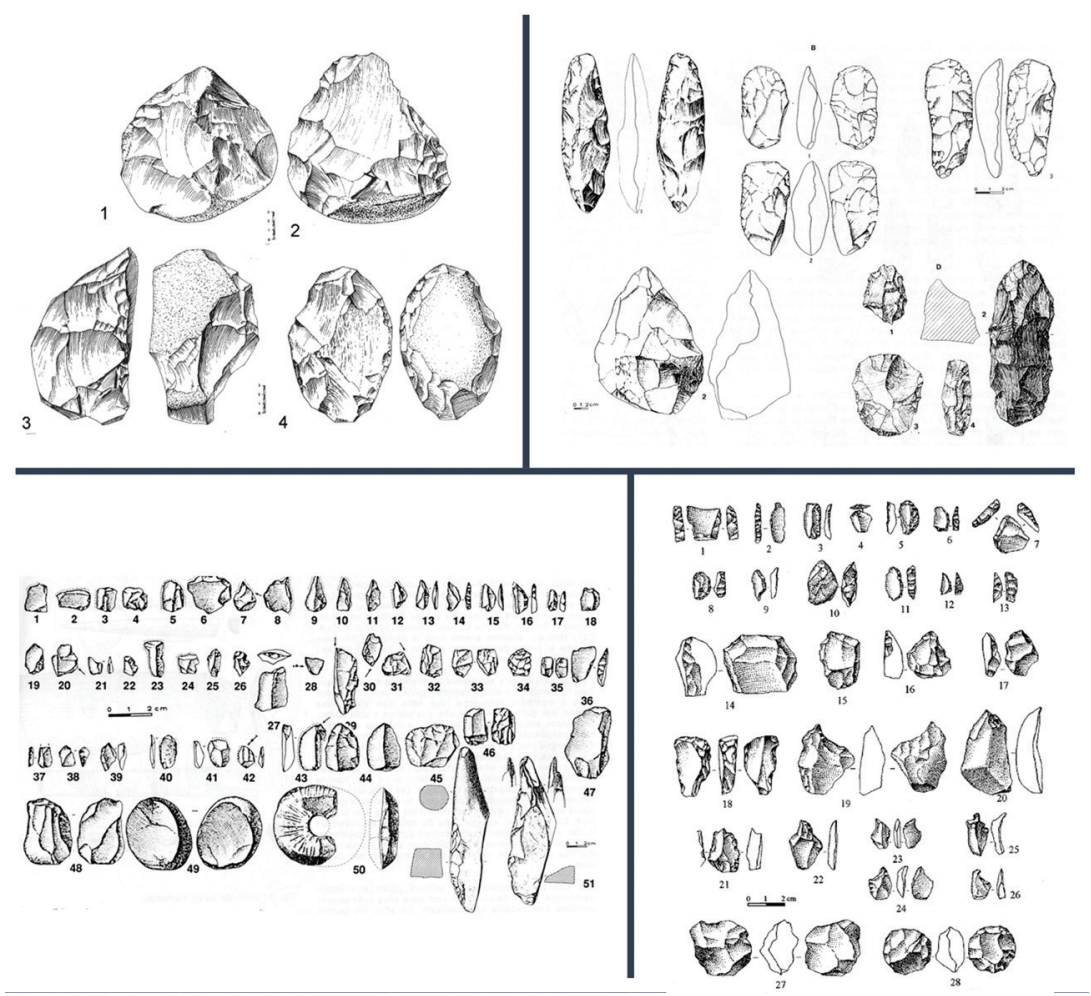

FIGURE 3.5 Pleistocene stone industries of Central Africa. Pleistocene stone industries of Central Africa: upper left, Sangoan from Gabon (Locko 1991a: 68-69); upper right, Lupemban from the DRC (Muya 1991a: 79); lower left, microlithic from Matupi cave, DRC (Muya 1991b: 119); lower right, microlithic from Shum Laka rockshelter, Cameroon (Cornelissen 2003: 15, fig. 8)

several historical trajectories and therefore several co-existing human groups. They appear not to be in close proximity to one another, but this observation is probably due to uneven archaeological fieldwork.

During pre-Holocene times, while hunter-gatherers had microlithic techniques in the northwest and eastern parts of the region (Figure 3.4, $\mathrm{n}^{\circ} 4$ and Figure 3.5), others used macrolithic bifacial techniques in Gabon and the DRC (Figure 3.4, $\mathrm{n}^{\mathrm{O}} 1-2$ and Figure 3.5). Later in the Holocene, the other communities turned to microlithic production techniques. Diversity was maintained with specific innovations entering the toolkits, for example in the Grassfields of Cameroon, such as polished stone tools from c. 7,00о-6,0о0 BP, and pottery from 5, ооо-4,ооо вр (Figure 3.6). Serious climatic deterioration around 7,10о6,900 вP in the Sahara and the Sahel appears to have caused new communities 


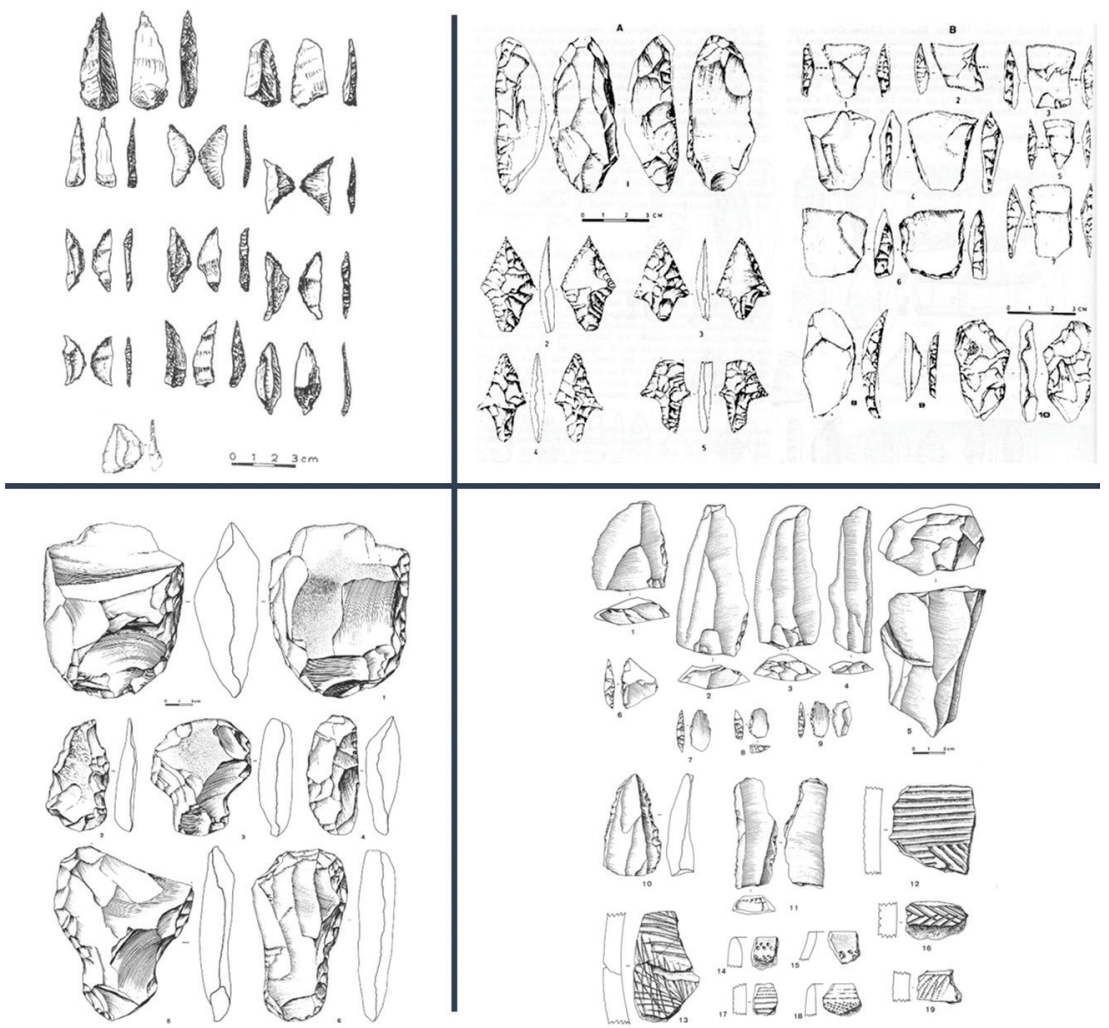

FIGURE 3.6 Holocene stone industries of Central Africa. Upper left, north-west Gabon (Locko 1991b: 110); upper right, plateau Bateke, DRC (Muya 1991b: 120); lower left and right, Shum Laka, Cameroon (Lavachery 1996, 1998 \& adapted in Clist 2006)

to slowly settle the Grassfields and introduce these new technologies (Bostoen et al., 2015: 362).

\section{Genetic Background of Hunter-Gatherers}

Generally, other than caves and rock shelters, environmental conditions are not conducive to the preservation of animal and human bones. The acidic soils of open-air sites often do not permit preservation beyond 400 years (e.g. Linseele 2018 for the Kongo Central province of western DRC), unless exceptional chemical peculiarities exist in places such as pits (e.g. Nkang in Cameroon and Toubé in Gabon, Van Neer 200o) or decomposing iron objects preserving pieces of bone or teeth in burials (e.g. Corisco Island, Gonzalez-Ruibal et al., 
2013). Because of the paucity of research relating to the Stone Ages, few sites have yielded human remains, and even fewer have been genetically analyzed (animals: see Van Neer 1990, 1991, 200o; humans: see Asombang 1988, Van Neer \& Lanfranchi 1985: 354, Mercader et al., 2001, Ribot et al., 2001, Crevecoeur et al., 2016; genetics: see Lipson et al., 202O, Wang et al., 2020).

This is why genetic studies turn to modern populations, especially rainforest hunter-gatherers (RHG), likely descendants of MSA and LSA communities of Central Africa. These studies suggest that the RHG split off from the main Homo sapiens lineage over 100,000 years ago (Lopez et al., 2019), diverging into the modern western and eastern Batwa some 20,00o years ago, with further internal differentiation amongst the western groups from 3,ооо вр (Verdu et al., 2009). Some evidence indicates a lack of interaction between villagers and hunter-gatherers before 1,ooo years ago (Verdu et al., 2014), and internal differentiation would then not be related to villager/hunter-gatherer contact. Significantly, the location of modern RHG groups correlates with some LSA cultures (Figure 3.7). The western groups north of the Congo River (Bezan, Kola / Gyeli, Baka, Aka, Koya / Kola, Bongo, and Barimba) are in the same area as the ancient Atlantic coastal and Tshitolean LSA industries; the central groups (Twa and Cwa) south of the Congo River correlate with other Tshitolean sites; and the eastern groups (Asua, Sua, Efe, and Twa), located in eastern DRC and East Africa, have a stronger spatial relationship with LSA industries typologically

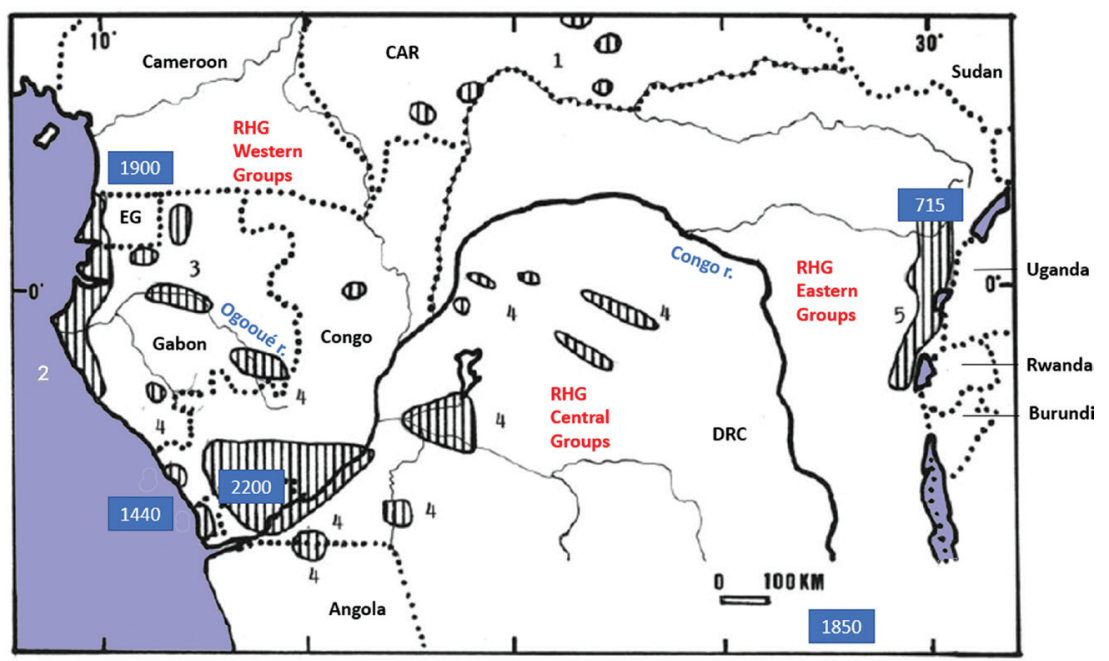

FIGURE 3.7 Holocene Late Stone Age cultures and latest stone-using hunter-gatherers (blue rectangles with в dates). 1: CAR sites, 2: Coastal sites of Equatorial Guinea and Gabon, 3: Dual influence sites in Gabon (coastal \& Tshitolean), 4: Tshitolean, Congo and the DRC, 5: East Africa related sites, 6: Grassfields of Cameroon FIGURE ADAPTED FROM CLIST 1995: 218, FIG. 73 
related to East Africa (Lanfranchi 1991a; Muya Wa Bitanko Kamuanga 1991b). In this context, the aDNA analysis of a 75 o year-old hunter-gatherer from the Matangai Turu rock shelter in the north-eastern part of the DRC (Mercader et al., 2001) indicates a possible relationship with Pastoral Neolithic peoples from East Africa (Wang et al., 2020).

\section{5 \\ Probable Interaction between Late Hunter-Gatherers and the Earliest Villagers}

Excavations in Central Africa have revealed stone-using peoples with stone-knapping techniques identical to LSA industries living near early villages and dated in the same time range (i.e. after 3,0о० BP). Sometimes, Iron Age potsherds and/or iron tools are also associated with lithics. The youngest of such interactions may be dated to around 700 вР in the Ituri forest of northeastern DRC (Mercader et al., 2000). But a few others exist (Figure 3.7): Ndtoua rockshelter at c. 1,90о ВР (Lavachery et al., 2005: 182) and Mbol at c. 1,87О в (Morin-Rivat et al., 2014), both in southern Cameroon, the Moulandou-Fouala site in Gabon at c. 1672 в (Livingstone Smith et al., 2007: 27), Kouilou River area in Congo at c. 1,240 ВP (Lanfranchi 1991b: 172), eastern Mayumbe range in the DRC at c. 2,200 вP (Clist, Bigohe et al., 2018: 16-17), Upemba depression in the Katanga province in the DRC c. 1,850 BP (Cahen 1975), and several others in Gabon (Clist 2006a: 300). The overall picture seems to be a gradual disappearance of stone working after contact with the first villagers, with differing scenarios as southwards moving villagers entered new territories. Two sites strengthen our observation, with continuous use of stone knapping since thousands of years ago and into the Iron Age: the Nangara-Komba and Shum Laka rockshelters, respectively in the CAR and in Cameroon.

At Nangara-Komba, the earliest Stone Age layers are dated to c. 6,100 BP and the quartz components are followed up to c. 200 BP (Lupo et al., 2021). They are coming mostly from small quartz and quartzite cobbles, producing microlithic assemblages under $4 \mathrm{~cm}$ size with rare tools. There is no significant change in the knapping technology throughout the deposit, from с. 6,10о вР to historical times (Ibid.). Pottery was probably imported from neighboring villages to the hunter-gatherer groups occupying the rock shelter during the later stages of its use, certainly since c. 2,40о вр, perhaps since c. 2,80о вр (Ibid.); some potsherds are decorated with rocking comb impressions, a technique similar to contemporaneous pre-metallurgical villages known in southern Cameroon.

The Shum Laka rockshelter in the Cameroon Grassfields (Figure $3 \cdot 7, \mathrm{n}^{\circ} 6$ ) provides evidence of hunter-gatherers with polished stone tools since 7,00o-6,ooo 
вР and pottery from around 5, ооо-4,ооо вР (Lavachery 1996, 1998, 2001, 20о3; Lavachery and Cornelissen 2000; Lavachery et al., 1996). On the basis of reconstructed vocabulary, proto-Bantu speakers knew pottery (Bostoen 2007), and researchers have considered the Shum Laka artifacts as representative of the original proto-Bantu toolkit (de Maret et al., 1987; see also Bostoen et al., 2015 for the latest). A recent genetic study on four individuals from burials dated to around 7,000 and 3,00о ВР, however, concludes that "these individuals are not representative of the primary source population(s) that were ancestral to present-day Bantu-speakers" (Lipson et al., 2020). These people were therefore stone-using hunter-gatherers, and up to 3,000 BP, did not have any physical interaction with villagers using pottery. Later, after 2,150 BP, iron tools and roulette decorated pottery were used together with the same LSA lithics. Neighboring Iron Age villages probably supplied these hunter-gatherers with a few pots, as elsewhere in the region. This explains why some researchers have noted a discrepancy between the developed LSA lithics of the Grassfields sites and the poor stone tools in the first villages in southern Cameroon:

il est impossible de comprendre, dans l'état actuel de notre ignorance, comment les préhistoriques sont passés de la confection d'une industrie lithique assez élaborée dans les Grassfields à celle d'une industrie très simple autour de Yaoundé. CLIST 2006B: 380

The re-evaluation of the late Grassfields LSA sites brings into focus an important research question: did people really establish villages in the Grassfields area, as a pit with pottery similar to the Obobogo Group of the Yaoundé area (Schmidt and Asombang 1990:14-15) and the few potsherds at Shum Laka and Fiye Nkwi rockshelters suggest (Lavachery 2001; Asombang 1988)? The alternative would be the pottery are imports from outlying villages to LSA communities, using long distance exchange networks, or the RHG themselves developed pottery making. Renewed research is needed in the Grassfields, and to the south, to look for these early villages (though for the time being, due to social unrest, this is not possible).

\section{Rock art}

Rock art is known throughout the region, although it has been studied in a very uneven way. Several styles, with differing techniques, are located on different surfaces, such as caves and rock-shelters walls and open air slabs and boulders (de Maret 1982; Loumpet Galitzine 1992). Possibly, open-air rock engravings 
were also painted, like the better preserved images in rock shelters in Congo and Angola (Ervedosa 1980: 233-391; Lanfranchi 1985; Gutierrez 1996). Since the mid-199os, research has led to new discoveries, re-interpretations of old data, and Accelerator Mass Spectrometry (AMS) dating. The latter has been put to use in the CAR at the Nangara-Komba site with a date to circa 500 в (Lupo et al., 2021: 10, table 1), in the western DRC where paintings are dated to the LIA and the time of the Kongo kingdom (Heimlich 2017), at the Ndalambiri site of west-central Angola dated to circa 8о вр (Rosina et al., 2018) and at the Tchitundo-Hulo Opeleva site in southwest Angola dated to circa 198о в (Gutierrez 1996: 190) where it relates to the LSA or possibly to the EIA.

The various rock art styles probably belong to at least two periods, as they do in Gabon (Clist 1995a: 184-197, 2005: 533-540), or in Angola (Martins 2014). They are thus also a marker of regional social diversity. We must reinterpret them and test their fit with the pottery sequences we now have, after having untangled their chronology and styles based on updated national catalogues (Angola-Ervedosa 1980: 233-391 and Gutierrez 1996; Cameroon-LoumpetGalitzine 1998 and Tchandeu 2016; CAR-Bayle des Hermens 1975: 265-277, 1984 and Clist 1991:199-201; Congo-Lanfranchi 1985 and Mongolo Mololi 2012, 2013; DRC —-Mortelmans $195^{2}$ and Heimlich 2017; Gabon-Oslisly and Peyrot 1993, Clist 1995: 184-197 and Oslisly 2016; Equatorial Guinea—Perramon Marti 1968 and Clist 2020).

\section{Interaction among Early Villagers}

Since the late 1950s, archaeology has been linked with linguistics to study the southwards expansion of Bantu-speakers whose homeland was located astride the Cross River in Nigeria and the Grassfields of Cameroon (Bostoen 2018). At present, it is only from southern Cameroon that one can document two movements of villagers, not yet using iron tools, between about 3,000 and 2,300 вр (Figure 3.8). These movements connect southern Cameroon to the Congo River along some 1,000 km of mainly forest with some interspersed savannas (Clist 2006a, 2006b).

The first and earlier movement seems to have followed the Atlantic Coast between 3,00о and 2,50о вр, linking the Obobogo (Cameroon), Okala (Gabon), and early Tchissanga (Congo) Traditions, or Groups (Figure 3.8, group A) (Nlend Nlend 2014; Clist 2005; Denbow 2014). Later, around 2,500-2,300 в в, a second movement with different pottery links the late Tchissanga (Congo) and the Ngovo (DRC) Traditions (Denbow 2014; de Maret 1986). We do not yet understand the connection, if any, with the first incomers and between 


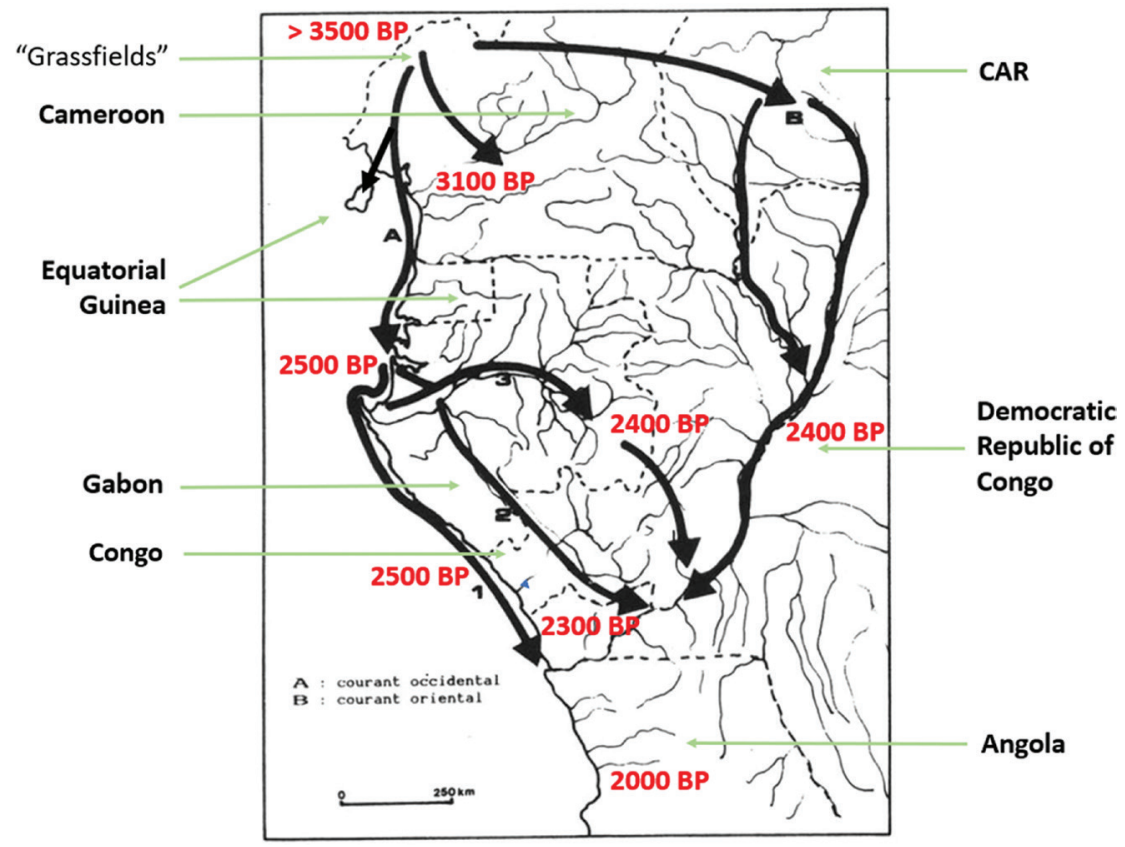

FIGURE 3.8 Probable axes of expansion of the first villagers in West-Central Africa. General timeline, the "A group" following the Atlantic Ocean coastline. The "B group" probably went through the forest and not along rivers as shown MARCHAL-NASSE 1991: 142, FIG.4, A MAP MADE BY B. CLIST - ADAPTED 2019 BY B. CLIST

them. Based on the distribution of the Okala Group, people probably travelled up the Ogooué River from the Atlantic coastline to reach Franceville and the savannas astride the Gabon-Congo border about $550 \mathrm{~km}$ to the southeast (Figure 3.8). The Okala evidence consists of a pit at Franceville dated to 2,440 вР, an undated archaeological layer at Massango with pottery and polished stone tools, and surface finds of dozens of polished stone adzes and axes in the province (Clist 1995: 147-149).

We still do not understand what happened there later, when iron smelting started in Moanda about 2,35 В $\mathrm{B}$ associated with a pottery still unpublished (Jézégou and Clist 1991), and with a pit at Djambala $200 \mathrm{~km}$ to the southeast on the Bateke Plateaux in Congo dated to 2,300 BP, containing pottery but without evidence of iron working (Lanfranchi 1991b: 172-173). Given that the Bateke Plateaux was not settled by iron-using villagers until 1,90о вР (Dupré and Pinçon 1997: 37-59), this data may represent a third axis of movement, from the north through the forests. Such a third axis is also suggested by the sites of Oyem (2,280-2,220 BP) and Koualessis (2,100-190о вP) in northern Gabon, and Okanda near the Ogooué River (c. 2,110 BP) where iron smelting was practiced 
(Clist 1989a: 81-83, 2005: 773-777). While iron metallurgy developed at Moanda and then slightly later in Oyem and central Gabon, the Okala Group material culture continued on the coast and in the middle reaches of the Ogooué River without evidence of iron production, though it probably imported iron tools from the inland production centers c. 2,370-2,200 в P (Clist 2005). Iron-working expanded on later with the establishment along the coast of Gabon and Equatorial Guinea of the Oveng Group from about 2,ооо вР (Sánchez-Elipe Lorente et al., 2016, and see below).

Far to the east, iron-producing Urewe Tradition sites are known in Kivu (DRC) (Hiernaux \& Maquet 1960), possibly dating to 2,800-2,500 BP and the highlands of the Interlacustrine area in Rwanda, Burundi, and Tanzania (Clist 1987, 2013: 26) (Figure 3.9). The geographical isolation at 2,30о в о of

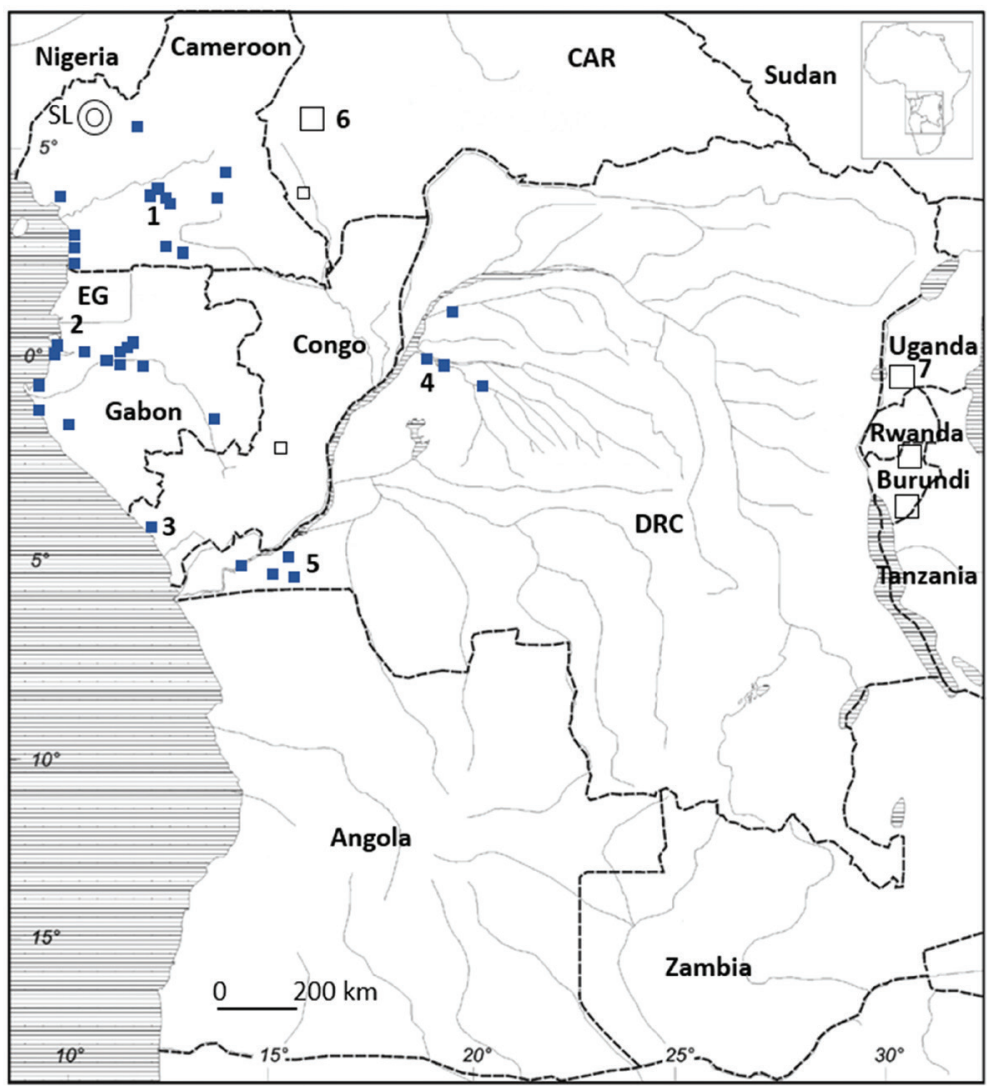

FIGURE 3.9 Pre-metallurgical villages maximum extension around 2,30о в (blue squares). SL: Shum Laka rockshelter and Grassfields. 1: Obobogo Group. 2: Okala Group. 3: Tchissanga Group. 4: Imbonga Group. 5: Ngovo Group. 6: Bouar area Neolithic and megaliths. 7: Early Iron Age Urewe Group

ADAPTED FROM CLIST 2005: 722, FIG.8-11 
the 'neolithic' villages in Cameroon, Gabon, and Congo, slowly expanding to the east and south, from the Urewe Tradition iron-producing settlements, is enough evidence to underline they are quite probably the result of two contemporaneous and separate social developments (Figure 3.9 and Ehret 2015).

We now know of another and distinct group of pottery-using villagers who maybe moved upstream through the forest along the Congo River, reaching east to the Kisangani area by 2,10о в (Livingstone Smith et al., 2017). If so, they may be related to the Imbonga Group located near Mbandaka on the Congo River, first dated to around 2,40о вр (Figure 3.8. Eggert 1987, 1994-1995; Wotzka 1995; Seidensticker 2016). The only possible origin for Imbonga communities is southeastern Cameroon, even though preliminary research there and neighboring Congo has not found any connections (Seidensticker 2016). But we cannot exclude the sites found around Kisangani relate to people arriving to the Congo river through the forests of its north bank. Ongoing research will certainly make the situation clearer in the years to come.

\section{Iron Working}

Two sets of facts from archaeology and historical linguistics must be considered to ascertain if the diffusion of iron working can be explained as an independent factor parallel to the expansion of the various EIA peoples. Historical linguistics told us long ago that metallurgy was not known to proto-Bantu speakers when they resided in the Cross River of Nigeria and the Grassfields of Cameroon (de Maret \& Nsukka 1977, Nsuka-Nkutsi \& de Maret 1982). Iron was a later introduction to Central Africa from the northwest, from Nigeria and Cameroon (Vansina 2006), which spread southwards (Clist 2012, 2013; Eggert 2014).

The earliest iron smelting centers developed in the north before 2,6оо вP in the western CAR (Figure 3.10, $\mathrm{n}^{\circ}$ : Gbabiri in western CAR - 2,640 BP), before being attested in southern Cameroon (Zili - 2,63О вР, Figure 3.10, $\mathrm{n}^{\circ} 2$ ), and around 2,3оо в і in southeastern Gabon (Moanda - 2,35о в , Figure 3.10, $\mathrm{n}^{\circ} 3$ ). Iron smelting then spread south and eastwards (Figure 3.10, $\mathrm{n}^{\circ} 4$ and 5 ) before ultimately reaching the Congo River and the Luanda area of Angola around 1,90о вР (Figure 3.10, ${ }^{\circ}{ }^{\circ}$ ). Once again, now using the respective chronology of west-central Africa's early iron-working centers and of the iron-producing Urewe Tradition of the Great Lakes area of eastern Africa (Clist 1987), we are left with the absence of any possible relationship between the two regions (Figure 3.10, $\mathrm{n}^{\circ} 1$ ).

No metallurgical analyses have been published from metallurgical sites. Such research is needed to verify the types of production sequence in the 

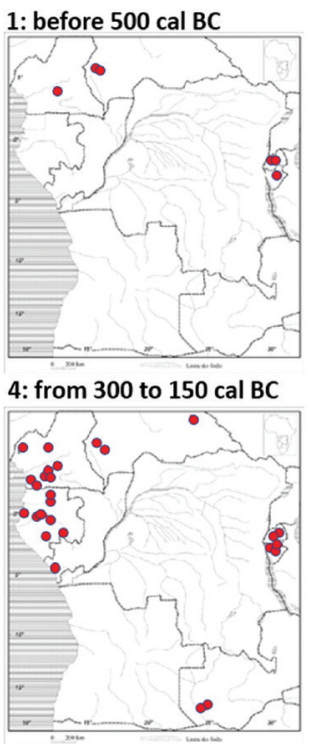

\section{2: from 500 to $400 \mathrm{cal} \mathrm{BC}$}

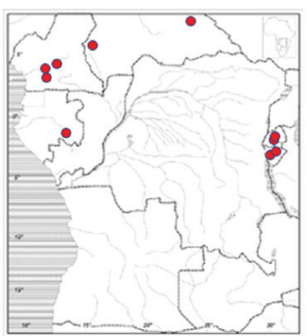

5: from 150 to $10 \mathrm{cal} \mathrm{BC}$

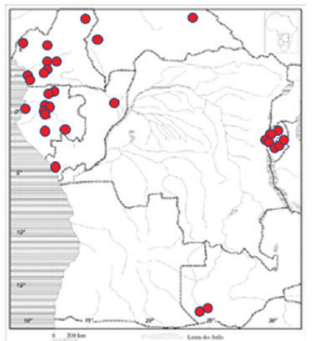

3: from 400 to $300 \mathrm{cal} \mathrm{BC}$

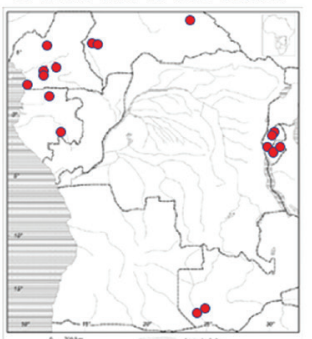

6: from 10 cal BC to cal AD 100

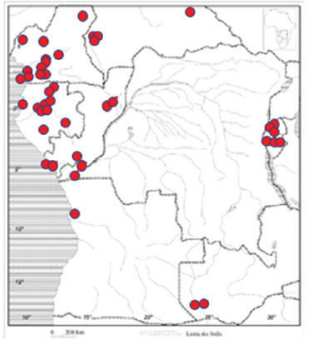

FIGURE 3.10 Geographical location and chronology of archaeological sites with iron-working evidence

ADAPTED FROM CLIST 2013, FIGS. 1-6

smelting process. We should also establish the ceramic links to clarify several peculiarities in the data at hand. For example, it is known the Oveng Group, extending from Equatorial Guinea (Sánchez-Elipe Lorente et al., 2016) to the south of the Ogooué River in Gabon (Livinstone Smith et al., 2007: 31-34), starts slightly before the Kay Ladio Group of the Kongo Central Province in the DRC (Clist et al., 2019). Their respective pottery are strikingly similar in several ways (Figure 3.11). Further investigation is needed in the context of the cultural transitions found between 2,200 BP and 1,900 вP from southern Cameroon to the western DRC and to the Inner Congo Basin (Wotzka 1995; Clist 2005; Seidensticker 2016).
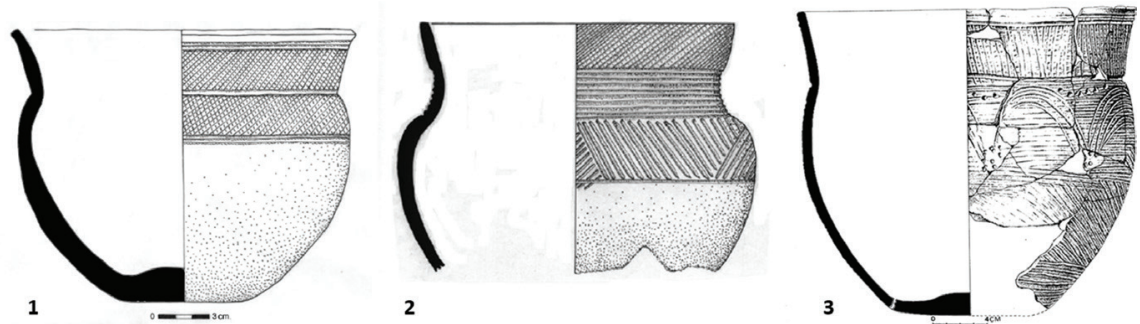

FIGURE 3.11 Pottery from the Oveng and Kay Ladio Groups. 1 \& 2 (from Clist 2005): Pottery from the Oveng Group, c. 2,00о-1,30о вP (Gabon), 3 (from Gosselain 1988): Pottery from the Kay Ladio Group, c. 1,950- 1,65O BP (DRC) 


\section{Cultural Transitions}

Probably the most fascinating research outcome during the last 40 years is the identification of cultural transitions (Figure 3.1). This research is often based on PhD projects, most of which unfortunately remain unpublished.

As previously mentioned, we easily follow Neolithic transitions which are in stark contrast to LSA traditions. The earliest such transition is slightly older than 3,000 BP in southern Cameroon, around 2,300 BP on the Congo River in the western DRC, and around 2,400 BP in the Inner Congo Basin (Figure 3.8). In the latter area, the earliest settlers may have been already connected to iron-producing centers as they did not use polished stone adzes and axes.

Though stone-using hunter-gatherers coexisted with villagers from then until modern times, losing along the way their stone toolkit (Figure 3.7), the Iron Age brought different pottery traditions. Such Neolithic/Iron Age transitions are situated between 2,200 and 1,900 в. They follow an irregular north to south chronological gradient, probably associated with the diffusion of iron smelting, but also with new waves of people moving towards the Atlantic coast. The spatial extension of their material culture is more restricted than during the preceding Neolithic, and shows marked stylistic differences along shorter distances.

These breaks are likely caused by a new human influx, replacing the previous production sequences, and changing the visual labels for group identification. Research on small cemeteries in southern Cameroon, southern Equatorial Guinea and northern Gabon revealed important differences in burial practice together with major changes in pottery production (CameroonMeister 2008, 2010; Meister and Eggert 2008; Eggert et al., 2006; Eggert and Seidensticker 2016. Equatorial Guinea- Gonzalez-Ruibal et al., 2011, 2013; Sánchez-Elipe Lorente 2015; Gabon-Peyrot et al., 1990, Clist 1995, 2005; and see below).

In this respect, four examples stand out illustrating similar scenarios: 1) southern Equatorial Guinea and northern Gabon; 2) the center of Gabon along the Ogooué River; 3) the coast of the Congo Republic; and 4) the DRC between Kinshasa and the Atlantic Ocean. We focus here on the first area, encompassing the Okala, Oveng. Nandá and Angondjé groups.

Throughout our review, we consider if one component is found on one site of a given cultural group, e.g. within the Okala Group, millet horticulture or stock raising, then it is probable all the villages of the group knew about it. Most excavations did not use flotation techniques to register millet seeds, and the soils are too acid to preserve animal bones. 
It was described early (Clist 1988, 1997) and is now bracketed by 44 radiocarbon dates from 2,460 to 1,870 BP. Okala communities are distributed over about $500 \mathrm{~km}$, from the Gabon Estuary to Franceville near the Congo border, and southward for about $300 \mathrm{~km}$ to the lagoons and forests south of Port-Gentil (Figure 3.12. See Clist and Jézégou 1991; Clist 1995: 151-153, 2005: 490; Assoko Ndong 2001, 2003). The sites appear to be true villages with a cluster of contemporaneous houses spatially organized. Ubiquitous pits of varying volume (from $0.5 \mathrm{~m}^{3}$ to $9 \mathrm{~m}^{3}$ ) yielded fragments of burnt clay walls with pole impressions of the wooden framework. Some excavations revealed post holes near the pits. These villages seem to extend over large areas: Kango 5 was 6 ha, while Okala 1 was at least 3.4 ha. Contemporaneous sites in Cameroon varied from 0.5 ha at Okolo and Ndindan to 1.5 ha at Nkang, 2 ha at Obobogo and 5 ha at

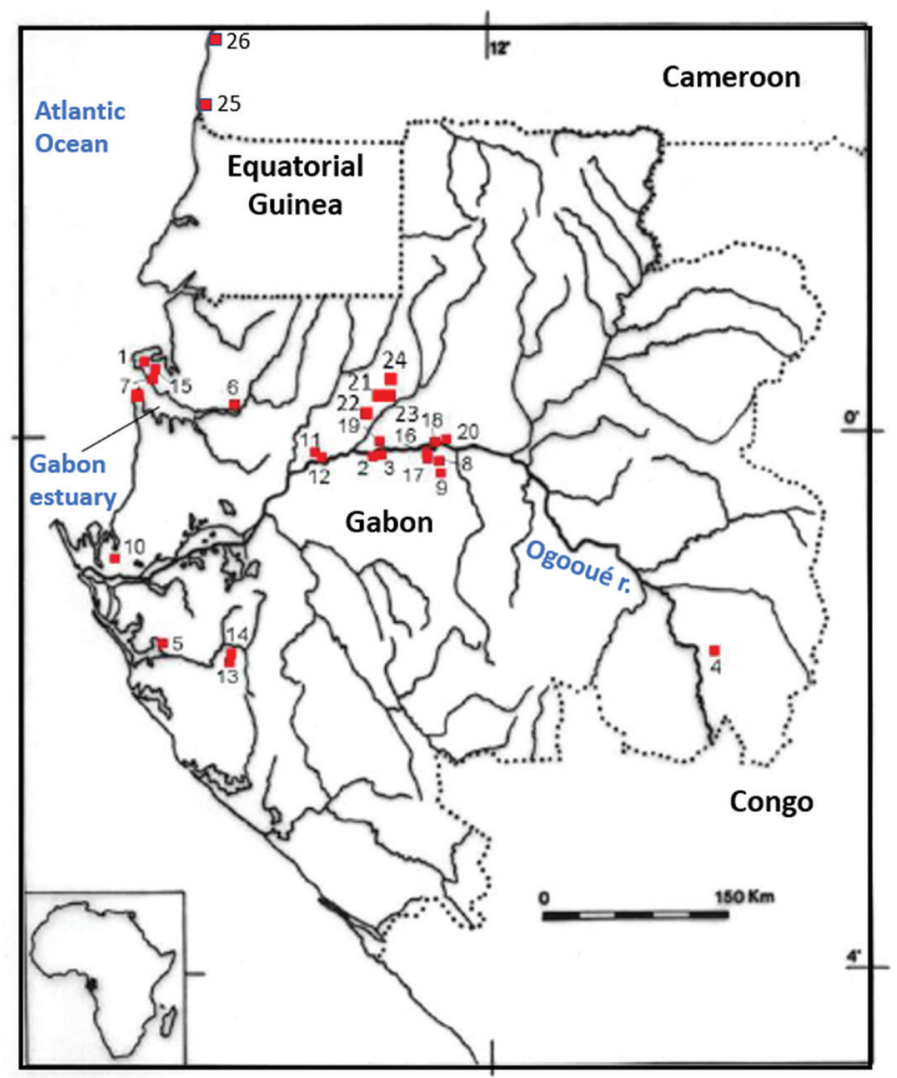

FIGURE 3.12 Map of the Okala Group sites in Gabon and Cameroon MAP BY B. CLIST 
Nkométou (Clist, 199o, p.466; Mbida, 1996, p.643; 2003, p.105). Pit fillings contained several artefact types, including pottery (sometimes in large numbers), a limited amount of stone tools, and polished stone adzes and axes, but no evidence of local iron working.

Within the characteristic Okala Group style, one decorative element stands out, the rocking comb, or spatula impressions, often covering the entire pot surface and at least $50 \%$ of the pots flat bottoms (Figure 3.13, lower four). One characteristic shape is the double-curve pot (Figure 3.13, right, upper two), which is also found in southern Cameroon 180 and $230 \mathrm{~km}$ to the north, at Campo Eglise and Bwambé, respectively. Villages using similar pottery both on the southern coast of Cameroon and in northwestern Gabon allows us to infer their concomitant presence on the Equatorial Guinean coast. Indeed, several sites with polished axes and grindstones have already been documented there (Clist 1998: 215-216). Forthcoming excavations will provide a clearer picture of
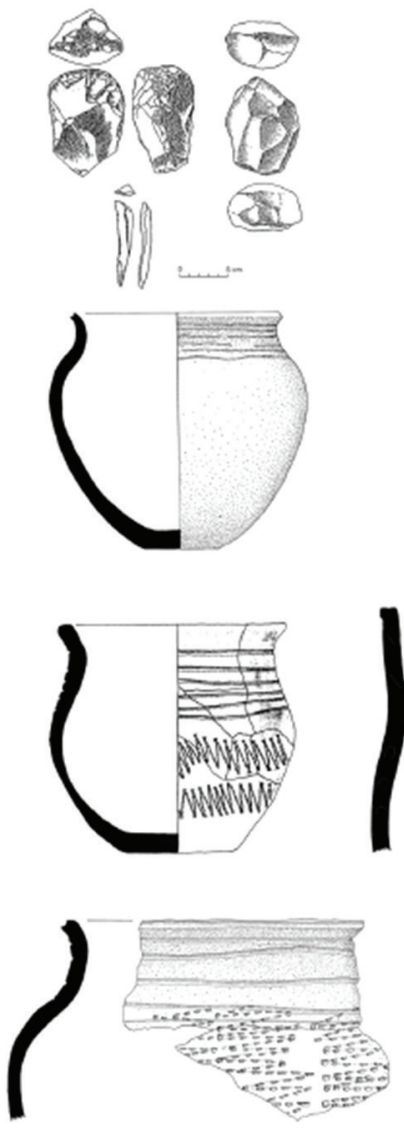
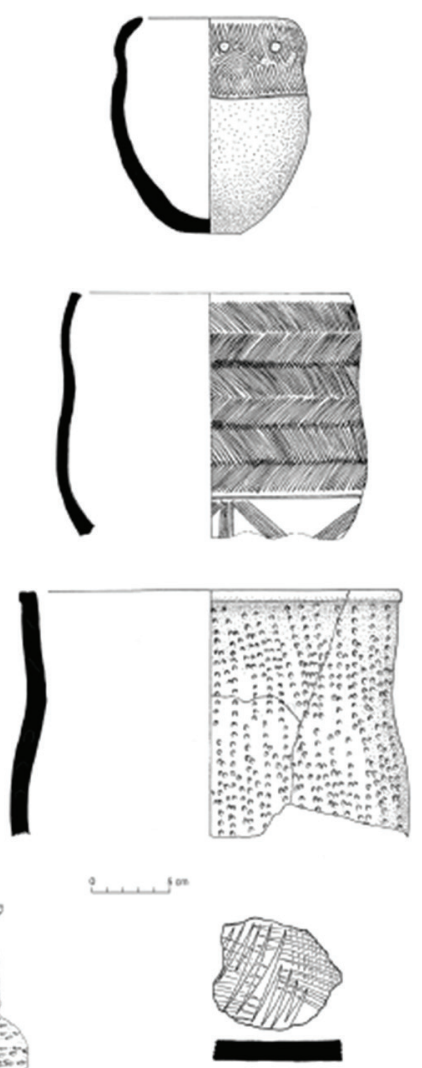

FIGURE 3.13

Okala Group pottery and stone tools $(2,460-1,870$ BP), Gabon CLIST 2006A, 297, FIG.4 
the socio-economic connections and exchange strategies that probably existed prior to 2,200 BP along $300 \mathrm{~km}$ of the Atlantic coastline. A close relationship between Okala and Obobogo pottery is already known (Clist 2005: 489-533 for Okala, 721-740 and appendix 5 for Obobogo/Okala). Another study, using material from more recent excavations along the Cameroon coast, showed all the sites before 2,200 BP were linked to the Gabonese Okala Group and formed a larger tradition (Nlend Nlend 2014: 230-273).

While feature 07/11 of Campo Eglise with typical double curve pots is late for the Okala Group 2,185-2,150 BP (Eggert \& Seidensticker 2016: 187), the four pits at Bwambé (pits n ${ }^{\circ} 12,16,19,33$ ) correspond to an earlier phase, 2,36o-2,240 вР (Nlend Nlend 2014). Pit $\mathrm{n}^{\circ} 33$ at Bwambé is very interesting. It is dated three times on millet seeds, palm nuts and charcoal extracted from the same layer in the pit ( $c f$. Nlend Nlend 2014: 147, 167, Table 39 and fig 65; Kahlheber et al.,

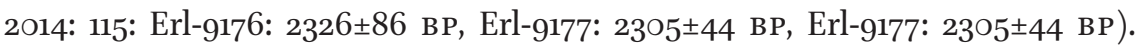
The fill contained as many shards from the so-called 'Malongo Tradition' as of the 'Bwambé Tradition', which are quite distinct (Nlend Nlend 2014: 148, 250 and Table 34). The 'Malongo Tradition' is equivalent to both the Obobogo and Okala Groups, a different label for the same material. Only a close examination of the pottery assemblages can distinguish these two Groups. As the double curve pots are unknown in the Obobogo Group, we can associate the Campo Eglise and Bwambé sites to an Okala cultural context. Millet is also found at Abang Minko'o dated around 2300-210о BP, some $200 \mathrm{~km}$ to the east, with pottery similar to the Obobogo Group (Eggert et al., 2006: 290 and Table 4: 283, pottery see their fig. 7). Millet seeds in Obobogo (Abang Minko'o) and Okala (Bwambé) contexts support the earlier identification of "two charred seeds of Monocotyledone, a grass of the genus Pennisetum sp" (Claes 1985: 137) found in two sherds from pits II (c. 3,055-3,070 BP ) and VII (c. 2,120 BP) at the eponymous Obobogo site and identified by H. Doutrelepont (Ibid.), though the seeds could also have been from the wild variety. The doubts about these identifications (e.g.Wotzka 2019: 411) underline the need to publish these excavations. Of course, renewed fieldwork, this time with systematic flotation, would be better. Unfortunately, the Obobogo potsherds studied by H. Doutrelepont could not be relocated (P. de Maret personal communication).

Domesticated millet at $c .3$,ооо вP contradicts the assumption that millet cultivation was difficult or impossible under rainforest conditions, and was only possible during the LHFC, i.e. after 2,50о вр (Neumann et al., 2012, and see historical development in Wotzka 2019). Wotzka has shown this is not true: millet could be, and has been grown at least until the 14th-16th centuries AD in the humid conditions of the forests (Wotzka 2019: 408 and his location map: 423 , fig.7). 
It clearly contradict[s] some of the major ideas held in the literature about a supposed general unsuitability of rainforest and climatically similar settings for pearl millet cultivation. WOTZKA 2019: 424

The use of millet may have been more widespread in this cultural context than is currently recognized due to the lack of the use of systematic flotation ( $c f$. Fuller et al., 2014). We can conclude millet cultivation was practiced in the Obobogo and Okala Groups, at least from southern Cameroon to northern Gabon. Its presence suggests former contacts between northwest Central Africa and the Sahel zone where it was domesticated (Neumann 2018: 8) and cultivated alongside cowpeas (Vigna unguiculata) in the Gajiganna Tradition and in the Nok culture of Nigeria (Neumann 2018: 13-14).

The use of the word *-cángú', designating finger millet in west Bantu languages, can be reconstructed for proto-Bantu. But it was probably associated with millet slightly later, after the start of the Bantu expansion (Bostoen 20o6207). Polished stone axes and adzes, grinding stones and grinders of the Obobogo and Okala Groups are indirect evidence for horticulture.

We tested the probability that early villagers chose specific soil types to settle and develop horticulture and fishing. We used soil maps of the French 'Bureau de Recherches Géologiques et Minières, and mapped a $5 \mathrm{~km}$ radius around 18 sites of the Okala Group. Six are along the Gabon estuary, ten along the Ogooué River, and two are the Ofoubou River sites (Figure 3.12, $\mathrm{n}^{\circ}{ }^{13}-14$ ). Although not conclusive, five sites have $80-90 \%$ cultivable land, five have 40-60\%, seven have 10-30\% and one has none (Otoumbi 13, Ogooué sector) (Clist 2005: 512-516). Fishing was certainly practised: fifteen sites are situated near the ocean or rivers. Even if communication between communities played an important role, this proximity to water implies the use of dugout canoes. Further, an iron fish hook was found in pit $\mathrm{n}^{\circ}{ }_{1}$ of the Bwambé site in Cameroon, dated to $c .2,200$ BP (Nlend Nlend 2014: 258). Prehistoric visits to nearby mangroves is attested by Anadara senilis shells (adapted to muddy river bottoms and mud flats in mangrove). They were found in pit $\mathrm{n}^{\circ} 1$ of Okala, and were probably collected around 2,230 вР (Clist 2005: 256). Okala Group villagers also exploited oil-containing tree fruits, such as the oil palm (Elaeis guineensis) and the incense tree (Canarium schweinfurthii). While Elaeis carbonized endocarps are found in most of the excavated pits, sometimes by the hundreds as at Okala, Canarium was only found at Toubé on the Ogooué River. The latter site also yielded carbonized endocarps from Anthrocaryon klaineanum and Coula edulis, while Panda oleosa was found at Okala and Toubé, and Maranthes polyandra at Kango. This is evidence for early agroforestry practices. On the Ogooué River, small stock raising is documented at Toubé 1 (Capra aegagrus 
f.Hircus), hunting at Otoumbi 13 (Tragelaphus scriptus and Cephalophus sylvicultor, Assoko Ndong 2002: 141), and at Toubé 1 (Tragelaphus scriptus and Atilax paludinosus, Assoko Ndong 2001: 230).

Long-distance exchanges existed. The Okala Group had come from the north and they must have had some knowledge of the lands crossed and kept social relationships with parent communities. Iron working is not attested on these sites. The two iron artefacts found at Okala and Lopé are evidence of long-distance contact with iron producing centres, maybe the one at Moanda some $55^{\circ} \mathrm{km}$ away. Raw material for the polished stone tools in estuary communities could have come from $80 \mathrm{~km}$ (Kango 5) to $70 \mathrm{~km}$ away (Okala 1), while 40 $\mathrm{km}$ was needed on the Ogooué River to reach the stone sources (Ndjolé Pk5). Lastly, the potting clay and temper used on the coast and along the Ogooué River are different. Several potsherds at the coastal Okala site may have been imports from inland, $300 \mathrm{~km}$ away:

La recette « minérale » quant à elle rappelle étrangement les productions du centre du Gabon. Là, les sites de la Tradition d'Okala fabriquent une poterie oxydée, claire, rougeâtre, probablement due à l'importance des oxydes de fer dans les argiles natives, dont la charge non plastique est composée du cortège minéral local, c'est-à-dire par ordre décroissant le quartz, le feldspath, le mica et l'amphibolite. CLIST 2005: 422

\section{The Oveng Group}

Research around the Gabon estuary (Clist 1989a) identified the Oveng Group. This Group extends from Corisco Island in Equatorial Guinea southwards to the Lambaréné area on the Ogooué River, $230 \mathrm{~km}$ away (Clist 1995: 164-167; Livingstone-Smith et al., 2007; Clist 2005: 541-599; Sánchez-Elipe Lorente 2015: 267-298). Eastwards, its inland extension is unknown, though the contemporaneous Otoumbi and Okala villages along the Ogooué River (Assoko Ndong 2002, Oslisly 1986, 1992) and in the forest to the north (Clist 1989a; Oslisly and Assoko Ndong 2006) using their own pottery show the 'border' was somewhere to their west (Figure 3.14). The Oveng Group is well bracketed by 25 radiocarbon dates between 1,970 and 1,296 в (an older date, Gif-8151 2,210 BP, from mangrove Anadara senilis shells is probably too old).

Local iron production started with the Oveng Group around the Gabon estuary, as is the case inland with the Otoumbi (c. 2,06о BP) and Okanda groups (c. 2,210 вР); all three appear at the same time, between 2,200 and 2,ооо в Р. The metallurgical residues and iron implements have not yet been studied. 


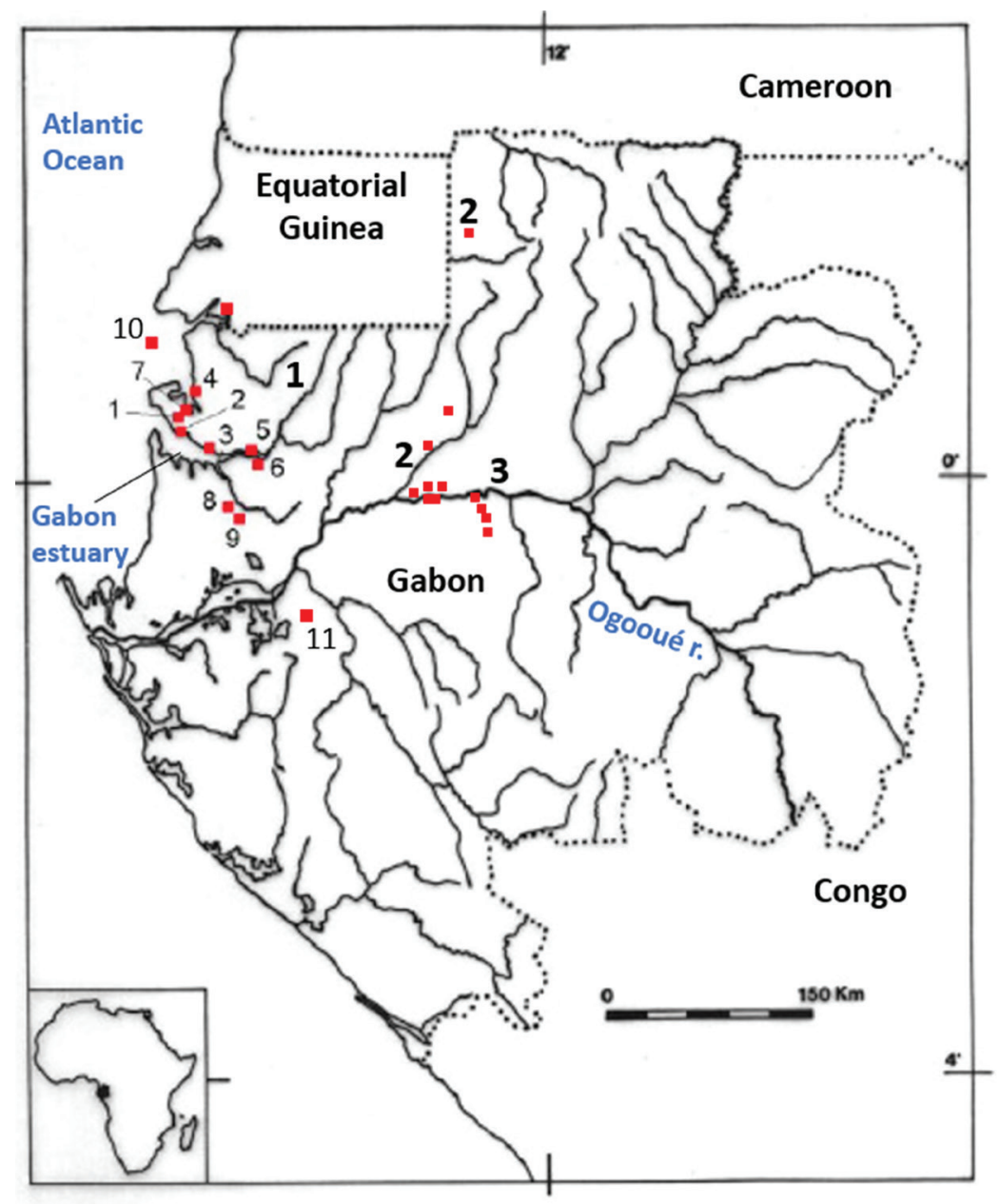

FIGURE 3.14 Location map of the Oveng (1, from $\left.\mathrm{n}^{\circ}{ }^{1-11}\right)$, Otoumbi $(2)$, and Okanda Groups (3)

Based on the ${ }^{14} \mathrm{C}$ dates, Neolithic and EIA settlements probably coexisted for some time (DIBAC database). ${ }^{1}$ Furthermore, on the coast the Okala (youngest date $c .1,87$ в вP) and Oveng Groups (oldest accepted date $c .1,970$ вр) overlap,

1 DiBAC: Datations absolues, Inventaires archéologiques et Bibliographies en Afrique Centrale. Absolute dates database created by B. Clist et R. Lanfranchi in 1987 (Cibadate project: $c f$. Sarrazin 1987), extended to cultural resources management and national archaeological bibliographies of Central Africa (Cultural resources management: Clist 1995, 238-244; absolute dates database: Clist 1995, 259-28o; bibliographies: http://www.african-archaeology.net/ biblio/index.html). All the ${ }^{14} \mathrm{C}$ data in this paper is taken from DIBAC. 
while inland, the Okala Group (youngest date $c .1,935$ BP) seem to have coexisted with the Okanda Group (earliest date c. 2,26о вр).

Vessel shapes are completely different from the preceding Okala tradition, though the bottoms are still flat. Decoration is limited to the upper parts, from the lip to the upper body, and new decorative techniques are in use (Figure 3.15, 1). Out of a minimum of 149 vessels at the Oveng site, only $25 \%$ are left undecorated. Of specific visual significance, the impressed comb is present on $37 \%$ of the pots, forming simple oblique or horizontal alignments, sometimes forming simple or multiple herringbone units ( $7 \%$ and $4 \%$ respectively). Rare $(\mathrm{n}=3$ pots), but visually significant, are the appliqués buttons — small conically shaped pieces of clay forming a single horizontal line (Figure 3.15, 1). Lips were sometimes decorated by small incisions (Figure 3.15, 1), as in the Otoumbi and Okanda assemblages. Lastly, another and very characteristic tool is the half-circular stylus (Figure 3.15, 1). It appears at the start of the EIA in all the cultural groups known in Gabon and used the same way: horizontal single or double lines bordering other decorative bands ( $c f$. Okanda and Otoumbi groups). In the Oveng Group it is present on $40 \%-56 \%$ of four of the six known shapes. This tool was used in the contemporaneous "Herringbone" pottery in Congo (Denbow 2014: 106-135), the Kay Ladio Group in the DRC (Clist et al., 2019) and in the Campo and Akonétyé groups of Cameroon (Meister and Eggert 2008; Nlend Nlend 2014; de Saulieu et al., 2015; Eggert and Seidensticker 2016). Some pots were also decorated with it within the Kribi Group of southern Cameroon (Nlend Nlend 2014).

Evidence for contacts between the Okanda and Oveng groups can be found in a pot uncovered at Oveng (Clist 2005: 566, fig.7-22, no 8 ) which is identical in shape and decoration to another from the Okanda 5 site over $200 \mathrm{~km}$ away (Assoko Ndong 2001:375, pl.38, R23), both dated to the same period (Figure 3.15, $2 \mathrm{~A}$ and $2 \mathrm{~B})$.

Carbonized endocarps of some fruits were found. As usual, Elaeis guineensis occurs in higher numbers, but the Oveng site also contained some Antrocaryon klaineanum, Coula edulis and Panda oleosa carbonized endocarps. Fruit trees as part of the subsistence system may have been inherited from earlier communities.

Excavation of the Oveng site added greatly to our knowledge of EIA ecological adaptations 2,00o years ago. For the first time in Central Africa, we had proof of adaptations to mangrove and ocean ecosystems: villagers fished (a lot), hunted (minimal), collected gastropods and bivalves in the mangroves, and fruits in the forest (a lot). Within their settlements set up in the forest they processed iron (Clist 1989a, 2005: 541-588, 2006c; Van Neer and Clist 1991; Van Neer 2000: 168 and 170). African manatee (Trichechus senegalensis) alongside 


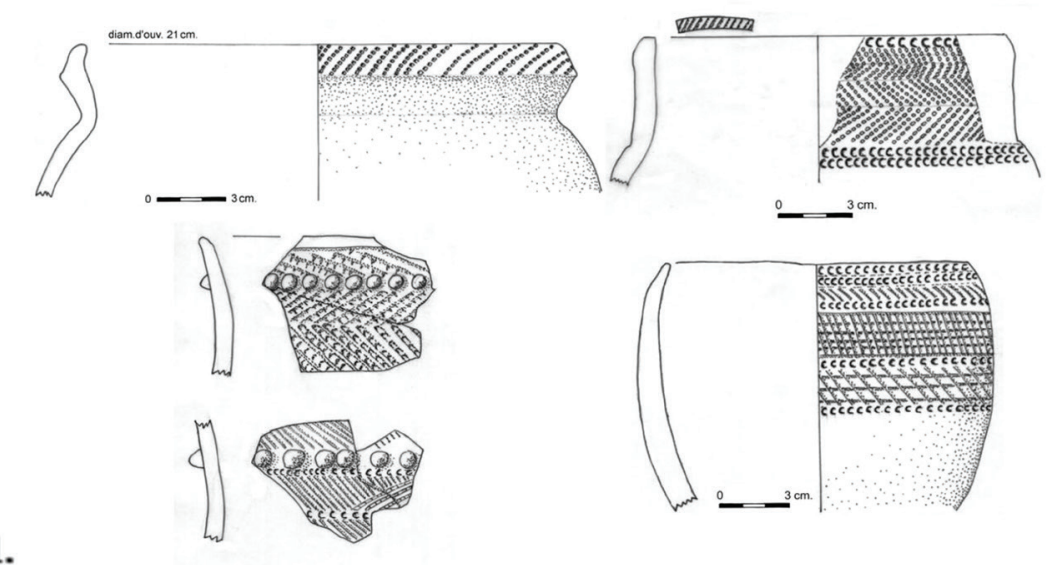

1.

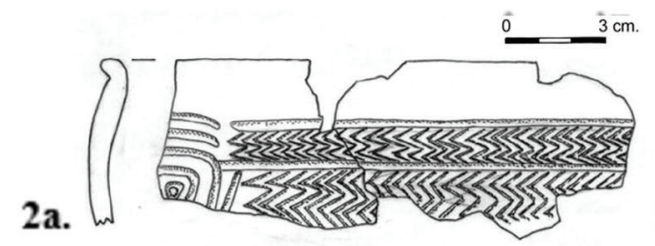

2b.
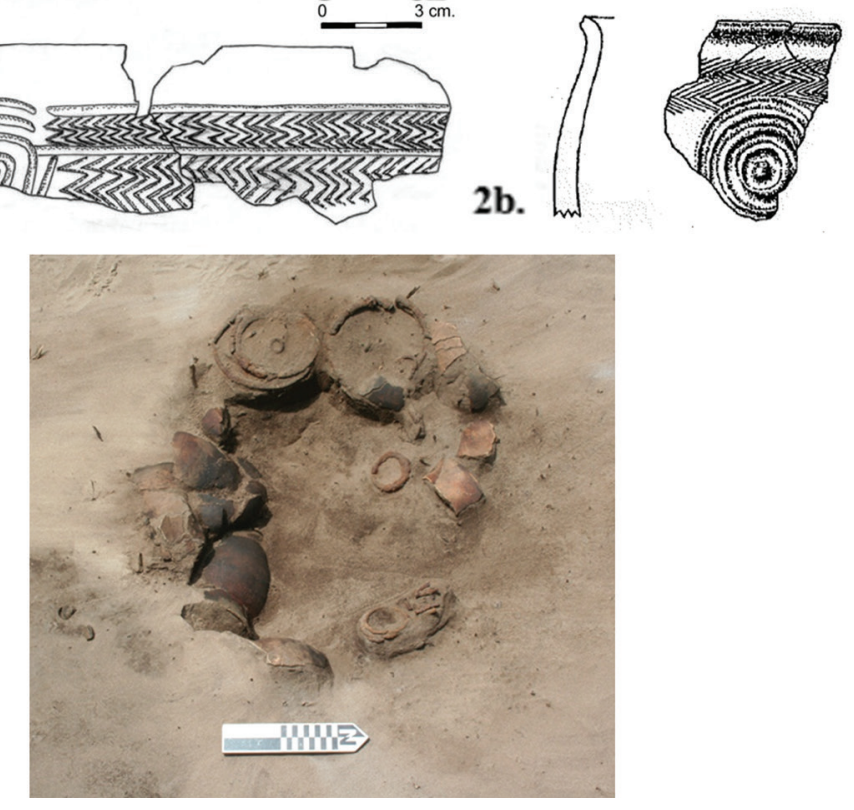

FIGURE 3.15 Oveng Group pottery and burial. Oveng Group, c. 1,970-1,296 BP. (1) pottery, Oveng and Kafélé sites, Gabon. (2a) Pottery from Oveng, (2b) Pottery from Okanda 5, (3) Burial of the Oveng Group. (fig. 1, 2a \& 5: Clist 2005, 2b: Assoko Ndong 2001, 3: Sánchez-Elipe Lorente 2015)

fifteen other fish species were fished in the mangrove rivers and in a nearby estuary, while the python was hunted on land (Python sp.). Although we systematically water sieved the deposits, we found no evidence of domestic seeds. Ten circular disc beads were made from shells, probably of Anadara senilis ( 2.5 to $3.6 \mathrm{~mm}$ in diameter, with a thickness from 0.4 to $1.5 \mathrm{~mm}$ ). The shell beads are similar to others found at the EIA midden of Cabolombo (ex-Benfica) near 
Luanda (Angola) dated to $c .1,8$ oо BP (Santos and Ervedosa 1970; Valdeyron and Domingos 2009, 2012), and to more recent shell beads at Muanda 6 on the DRC coast dated to $c .1,600$ вP (Clist, Bigohe et al., 2018; Clist and Béarez et al. Forthcoming). Together with the Muanko Lobethal site in Cameroon, dated to between 1950 and 175 о в which yielded oyster shells (Williams-Schmid 2001; Eggert 2002: 513-521), the shells attest to a better EIA adaptation to coastal ecosystems compared to Neolithic times.

In 2009, a survey on Corisco Island (Equatorial Guinea) identified important features impacted by the construction of an airstrip. Several of them were radiocarbon-dated (Gonzalez-Ruibal et al., 2011). Analysis of the 2011 excavations (Gonzalez-Ruibal et al., 2013; Sánchez-Elipe Lorente 2015) revealed interesting burial practices of the Oveng (Figure 3.15, $\mathrm{n}^{\circ} 3$ ) and Nandá groups that are similar, but different from contemporaneous burials in southern Cameroon (Meister 2008, 2010; Meister and Eggert 2008; Eggert and Seidensticker 2016). The iron artefacts from 22 Oveng burials comprise axes, bikuele (traditional iron currency used in the LIA with exactly the same shape), bracelets, knives, necklaces, rings and spoons. They number from zero ( 4 burials) to nine per feature; exceptionally one had 14 and another 27 . One iron necklace from burial $\mathrm{n}^{\circ} 2 \mathrm{O}$ had a bone fragment preserved by the decomposed metal; other pieces of human bone were also found in another three deposits (Gonzalez-Ruibal et al., 2013; Sánchez-Elipe Lorente 2015). Whole pots occurred in burials without iron implements, while 15 burials with metal lacked pots. In the remaining seven burials, the pots number from one to five (Gonzalez-Ruibal et al., 2013; Sánchez-Elipe Lorente 2015, and our Figure 3.15, $\mathrm{n}^{\circ}$ ). The cemeteries in Cameroon consisted of primary burials in oval-shaped pits, while on Corisco there were secondary burials in circular pits, though two elongated pits were also documented. Further, some types of iron artefacts were found in Cameroon but absent in Equatorial Guinea. The associated pottery was inverted in Cameroon, while they were upright on Corisco Island. The pottery found in the burials helped to identify the Akonétyé, Campo, and Oveng stylistic zones. Significant similarities between the three zones over about $300 \mathrm{~km}$ include iron artefacts, such as spoons, anklets, axes with widened cutting edge, and bundled iron pieces interpreted as special purpose currency. But comparisons between the Akonetye, Campo and Mouanko Lobethal sites in Cameroon (Figure 3.16) show they form a group quite distinct from Oveng in Equatorial Guinea (Meister 2010). A previous find in the suburbs of Yaoundé, at Obobogo, was probably part of a cemetery similar to the other sites in Cameroon (Meister 2010: 239-240).

The emergence of inequalities and the development of inegalitarian polities in sub-Saharan Africa will eventually be found in the northwestern part of 


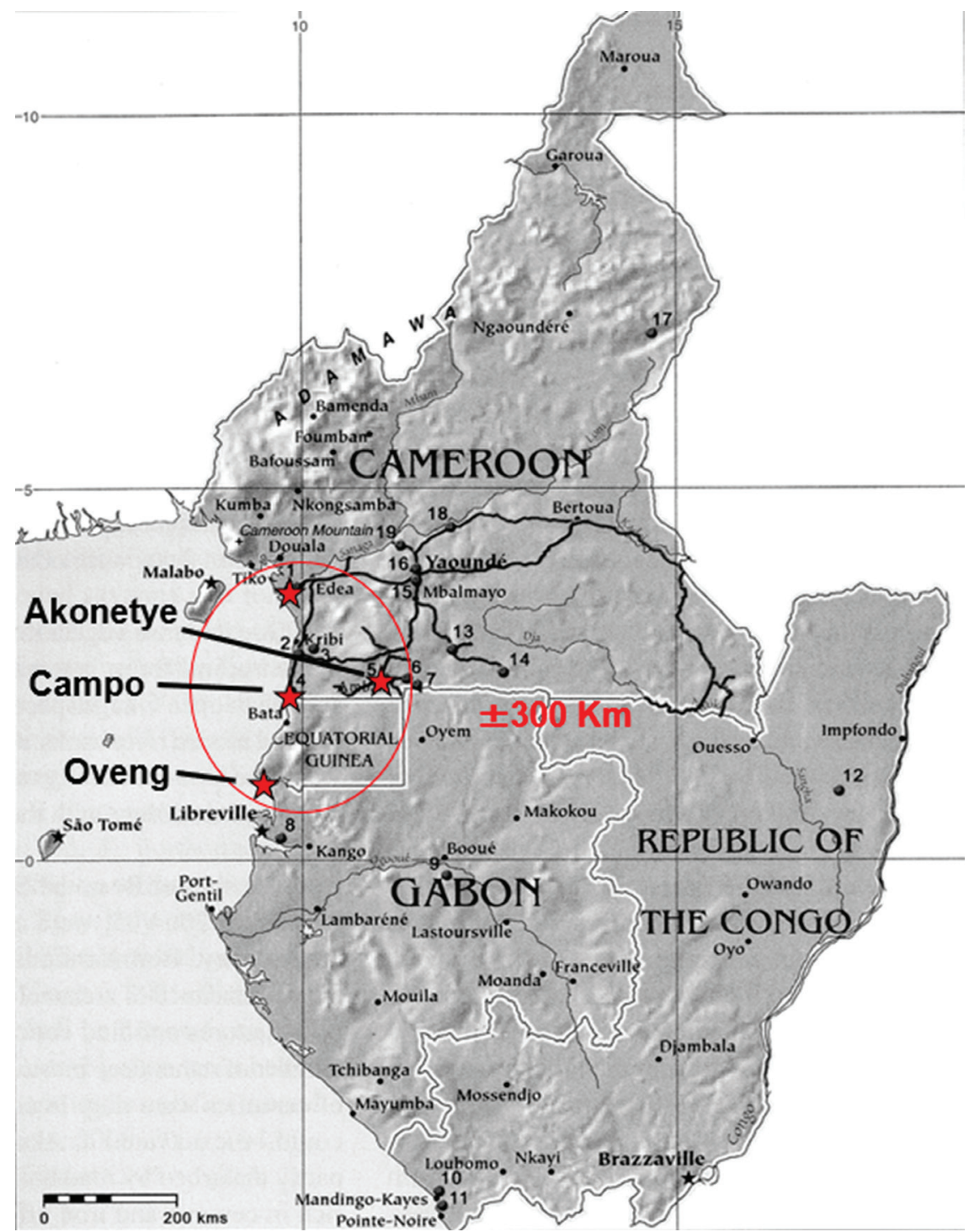

FIGURE 3.16 Position of the four cemeteries associated with the Oveng, Campo, and Akonetye Groups

ADAPTED FROM EGGERT ET AL 2006: 280, FIG. 2

Central Africa, from Cameroon to Gabon. Indeed, the political and symbolic relevance of iron to wives and wealth is probably much older than previously thought (Gonzalez-Ruibal et al., 2013; Eggert and Seidensticker 2016). Taking into account the oldest Oveng burials, we can push back to the ist century AD 
the development of prestige goods to enhance political formations (Vansina 1990, 1999; McIntosh 1999; de Maret 2012). The possible historical relationship between the EIA Groups of southern Cameroon, Equatorial Guinea and Gabon with peoples south of the rainforests suggests these emerging traditions could have been implicated in the later rise of the Kongo kingdom (de Maret 1999, 2018; de Maret et al., 2018; Clist, de Maret et al., 2018a, 2018b).

We must now consider the Otoumbi Group in central Gabon dated from c. 2,оОо BP. Though identified some time ago (Oslisly 1992), we can only call attention to the similarity between Otoumbi and Oveng pottery, in contrast to Okanda ware. Its corpus of ${ }^{11}{ }^{14} \mathrm{C}$ dates, together with 18 from the Okanda Group, and the respective distribution maps, show that Okanda preceded Otoumbi. Later, Okanda settlements moved further east, while Otoumbi communities expanded in their sector. The Oyem EIA site located $180 \mathrm{~km}$ north, dates to $2,200 \mathrm{BP}$, has pottery similar to Otoumbi and suggest this Group may have come from the forests at the Cameroon-Gabon border (Figure 3.14; Oslisly and Assoko Ndong 2006).

These two groups in northwest Gabon were originally called 'Groupe II' and Angondjé Group (Figure 3.17) (Clist 1995: 167-168 and 168-169, 1995b: 18-20; Sánchez-Elipe Lorente 2015; Sánchez-Elipe Lorente et al., 2016). The Nandá Group (formerly Groupe II) is dated by ten ${ }^{14} \mathrm{C}$ results from 1,360 to 907 BP and the Angondjé Group by eight dates from 985 to 440 в . However, it has been suggested the two cultural groups may be two sides of the same coin. After having stated

the small number of radiocarbon dates from Gabon associated with the Nandá tradition and the larger assemblage of dates from Corisco suggest that the traditions coexisted, at least in Corisco", SÁNCHEZ-ELIPE LORENTE ET AL., 2016: 364

he further suggested

the pottery traditions Nandá and Angondjé do not represent two different human groups; rather, they belong to the same tradition but relate to two different communities of practice - everyday life and burial. 2016: $364-365$ 

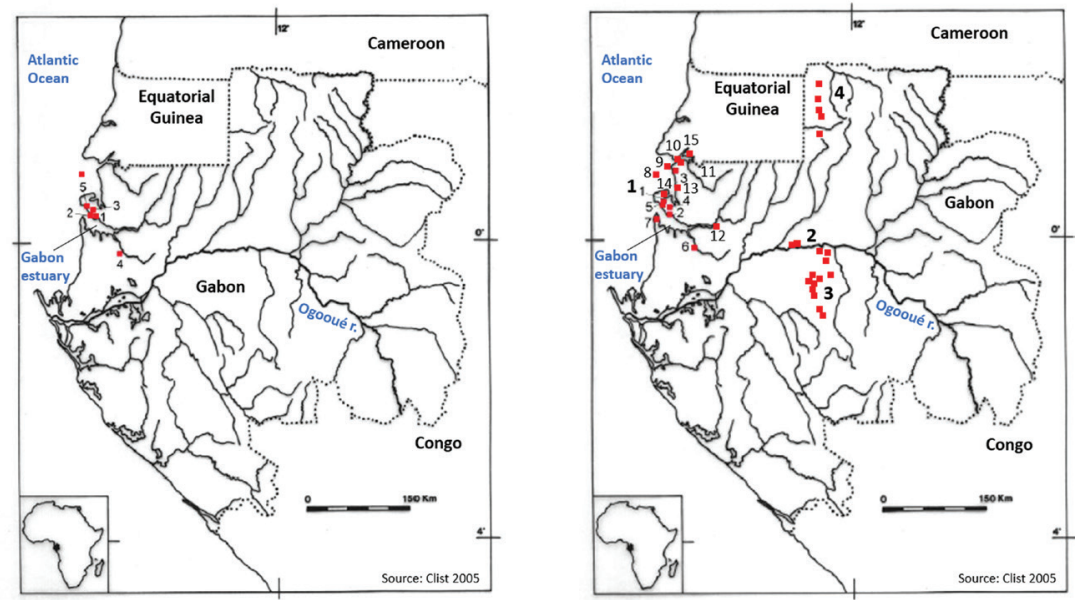

FIGURE 3.17 Location map of Late Iron Age Groups in Gabon. Sites from the Nandá Group, c. 1,36о-907 вP (left) and from the Angondjé Group, c. 985-440 в (right, $\left.\mathrm{n}^{\circ} 1\right)$. Also illustrated, the Lopé Group $\left(\mathrm{n}^{\circ} 2\right)$, the Leledi Group $\left(\mathrm{n}^{\circ} 3\right)$, and LIA dated sites near Oyem $\left(\mathrm{n}^{\circ} 4\right)$

13 The Nandá Group

The 16 Nandá burials on Corisco Island yielded iron artefacts and pottery (Figure 3.18, $\mathrm{n}^{\circ} 1-3$ ). They contained from zero ( 5 features) to 12 iron objects. All of them had pottery, mostly from one to eight vessels, while one with 18 pots also contained six iron objects. The iron artefacts consisted of anklets, axes, small bell (1), bracelets, necklaces, and knives (Figure $3.18, \mathrm{n}^{\circ} 3$ ). The number of iron artefacts is less and the pottery more abundant than during Oveng times. Pottery assemblages are limited to a few jars (Figure 3.18, $\mathrm{n}^{\circ} 1,2$ and 4 ) and many bottles (Figure 3.18, $\mathrm{n}^{\circ} 3$ and 5 ). The types of metal and pottery offerings are different from the Oveng Group, and we have no evidence for the exploitation of local mangroves. The corpses were set the head to the southwest, feet to the northeast, with bent arms and hands placed on the chest and belly (Gonzalez-Ruibal et al., 2013:136). The pottery, especially the bottles, may have been produced specifically for funerary purposes because

the pots were barely fired and they crumble easily when they are removed from their original position; on the other hand, it seems that they were made quickly, as proved by the deficiencies in the modeling (using coils) and, especially, the often clumsy decoration. GONZALEZ-RUIBAL ET AL., 2013: 138 


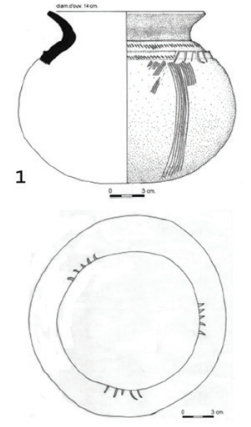

1.

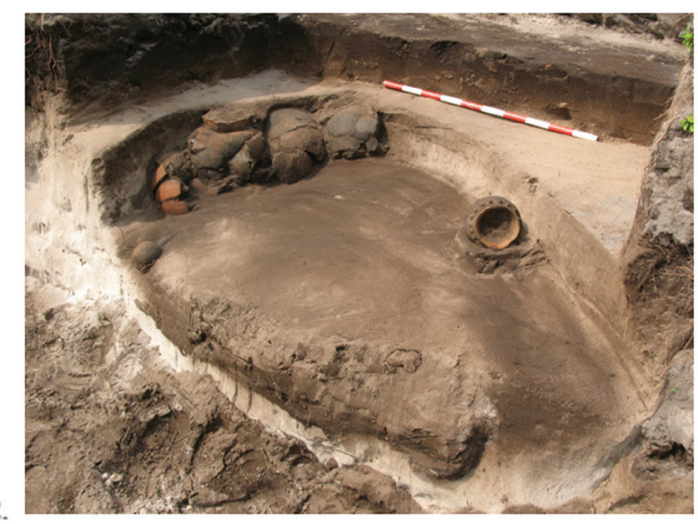

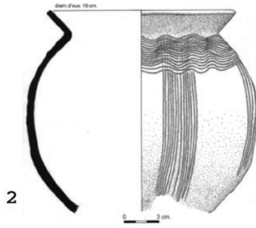
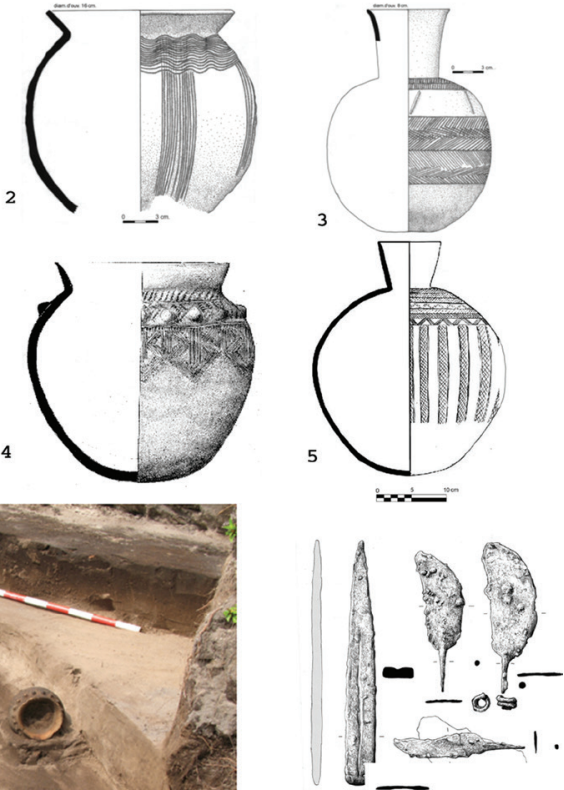

3.

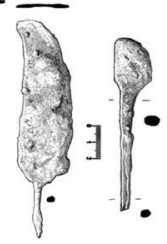

FIGURE 3.18 Nandá Group pottery and iron artefacts from burials. Nandá Group, c. 1,360-907 BP. (1) Pottery from the 'Sablières', Gabon $\left(\mathrm{n}^{\circ}{ }_{1-3}\right)$ and from Corisco Island, Equatorial Guinea $\left(\mathrm{n}^{\circ} 4-5\right)$ (Clist 2005, Sánchez-Elipe Lorente 2015). (2) Burial $n^{\circ} 9$ from Corisco Island (Gonzalez-Ruibal et al., 2013, 137, fig.17). (3) Iron artefacts from burials $n^{\circ} 26$, Corisco Island (Sánchez-Elipe Lorente 2015)

At the 'Sablières' site in Gabon, however, all pottery was well made and finely decorated (Peyrot et al., 1990; Clist 2005: 6oo-614). One of these pots was found on the northern part of Bioko Island (Peyrot et al., 1990: 496). When it was published, a connection to Nigeria was suggested (Martin del Molino 1965: 26 and fig. 10B). Instead, this is evidence for long-distance contact between Bioko and Nandá coastal villages, probably located around the Rio Muni or the Gabon estuary. This find strengthens cultural links over some $300 \mathrm{~km}$ between southern Cameroon and the Equatorial Guinea-Gabon border (Figure 3.16), and, notably, highlights long-distance contacts since the Neolithic, 1,ooo years previously. 


\section{The Angondjé Group}

The Angondjé Group still had settlements around the Gabon estuary (Clist 2005) when the Portuguese sailed along the coast between AD 1471 and 1475 (Merlet 1990: 18). The occupation at Okala, north of Libreville, is dated to AD 1406-1631 (Gif-8152: 440 BP). A pit at Bisségué 1 contained Angondjé ware and European glazed pottery from the 16th century (Clist 2005: 681). The earliest date for this Group dates back to calAD 991-1153 (CAN-1564: 985 BP on Corisco Island). Since then, the peoples living on the coast from at least the Gabon to the Muni estuaries and its adjoining islands shared a common material culture. Its most characteristic artefacts were carinated cooking pots with convex bottoms, clay beads, clay lid knobs with appliqués or incised decorations and iron swords (Figure 3.19). As no cemeteries have yet been excavated, we do not know the range of iron implements produced. But the Angondjé site has shown evidence of post holes, some organized to form the corner of a possible quadrangular house, and the use of deep pits (Clist 2005: 632-652).

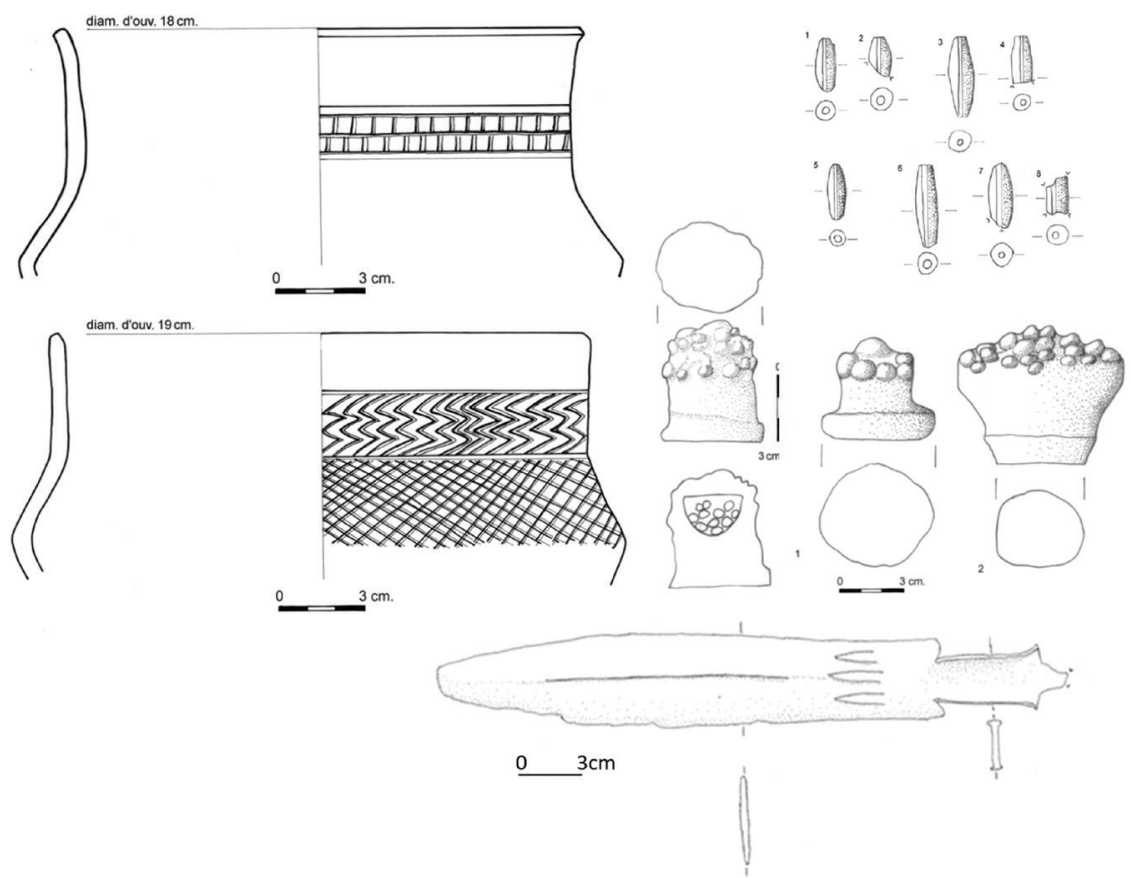

FIGURE 3.19 Angondjé Group pottery and other artefacts. Angondjé Group pottery, clay beads, decorated clay lid knobs, and iron sword (985-440 ВР)

CLIST 2005 
Wood carved roulettes were used to decorate Angondjé Group pottery on the Muni estuary near Corisco Island (Clist 1989a: 87, fig.14 and our Figure 3.20, $\mathrm{n}^{\circ}{ }^{1-2}$ ). This is a southern extension of their geographical distribution from West to East Africa (Livingstone Smith 2007).

Looking to the east, towards the Ogooué River and central Gabon, we have a strikingly different archaeological picture (Assoko Ndong 2002, 2003). As is often the case regarding the LIA, it has not been as thoroughly studied as older periods. Nevertheless, the Lopé and Lélédi groups have been identified (Figure 3.17, right, $\mathrm{n}^{\circ}$ and 3 ). It is noteworthy that LIA settlements along the Ogooué and adjoining forests lack pits (Assoko Ndong 2002: 151, 2003: 121). This helps to explain the paucity of ${ }^{14} \mathrm{C}$ dates because archaeologists often miss sites without these dark filled pits (Assoko Ndong 2001: 473). In terms of ceramics, fiber-roulette decoration characterizes Lopé ware (Figure 3.20, $\mathrm{n}^{\circ} 3$, and Assoko Ndong 2002: 152-154). Eight ${ }^{14} \mathrm{C}$ dates put Lopé material culture at. 820-250 в $\mathrm{P}$. Sometime within this sequence, tobacco pipes (at least post $c$. AD 16oo, see Clist 2018) and European pottery appear. On the other hand, the Lélédi Group further south in the forest (our Figure 3.17, right, $\mathrm{n}^{\circ} 3$, and Assoko Ndong 2002: 154-155) is more similar to the Otoumbi ware than to the Lopé ware (see Assoko Ndong 2002: 153 , fig.12, $\mathrm{n}^{\circ}$ ). Ten radiocarbon dates place it at 86о-8о вр. This means the peoples who produced the Angondjé, Lopé and Lélédi material culture were contemporaneous and probably like their ancestors had long-distance contacts with each other. Further and more exhaustive publications are needed to evaluate the diversity of central Gabon's LiA. It must be noted that wooden-roulette and fiber-roulette decoration have been found at the Mayoko iron mine in Congo a few kilometers from the Gabonese border, dated from 5 Оо вр (Ndanga et al., 2013a, 2013 b), and significantly extends the known distribution of such pottery.

To be exhaustive, we note several LIA sites in the Woleu Ntem Province in northern Gabon (Figure 3.17, right, $\mathrm{n}^{\circ}$ ). Since their excavations in the late 1980s, no other fieldwork has developed the local sequence (Assoko Ndong 1988; Clist 1987b, 1987c, 1989b, 1989c, 1993; Meye Medou 199o). At present, both settlements and iron smelting sites are recorded, dated to between $360-140$ в by five radiocarbon results. These sites must be associated with the Fang before they moved towards the coast to trade with European merchants (Merlet 199o: 91-134). The archaeological furnaces, it is worth noting, are identical to ethnographic descriptions in Fang territory by G. Tessman (1923) and C. Von Morgen (1893). The oldest ${ }^{14} \mathrm{C}$ date comes from the Mbam furnace which calibrates to AD 1433-1664 (Clist 1993). 

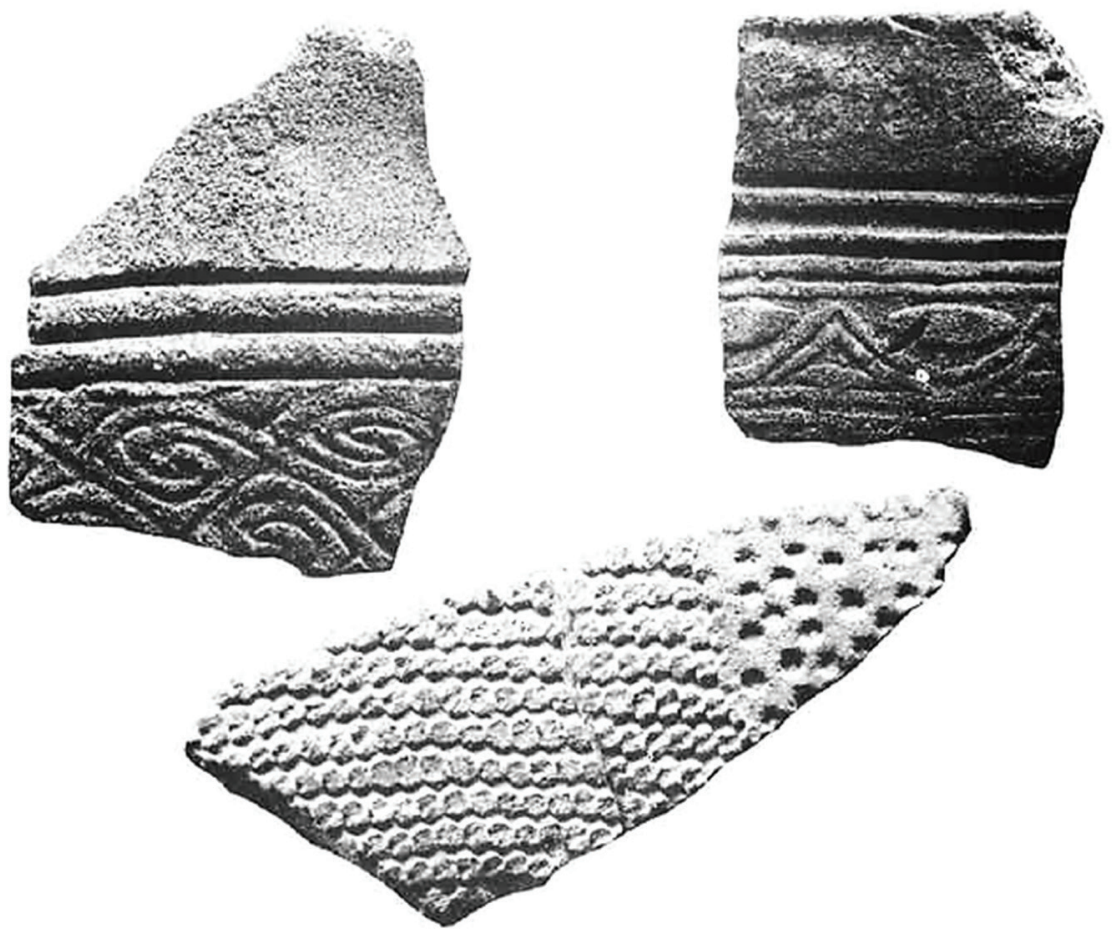

FIGURE 3.20 Roulette decorated potsherds from Angondjé and Lopé Groups context. Carved wooden roulettes decorated potsherds from Angondjé Group, and fibre roulette from Lopé Group

ILLUSTRATION FROM CLIST 1989A: 87, FIG. 14

15

\section{Conclusions}

We have shown the complexity of the material-culture sequence over the last 30,0oo years. This long period saw successive waves of people, stone and pottery using, occupying and re-occupying large tracts of land from the northern to the southern savannas of Central Africa. Such diversity probably parallels genetic and linguistic diversity in this vast region.

Following the Stone Ages, Neolithic villagers first settled along the coast from Cameroon to Congo and inland along the Ogooué River in Gabon from 3,000 to 2,400 BP. Probably from southern Cameroon, another group made its way through the forests to enter the Inner Congo Basin around 2,40о B P. Some rare early sites in southeast Cameroon and southwest CAR may connect Cameroon to the Congo River. The LHFC of 3000-2000 BP only helped this 
dispersal, rather than caused it, as evidence exists of pre-metallurgical peoples inhabiting the forests before then. Furthermore, the often cited Sangha River Interval savannas seems not to have existed. It would explain why the first villages did not appear there in the forest before 2,200 BP.

Iron smelting is not older than 2,400 BP in the northwestern rainforest, and it was probably transmitted via an already pre-existing network of longdistance exchanges. It is not clear yet if iron-working techniques diffused independently, or were also associated with the expansion of peoples seen in the archaeological record from 2,200 BP. This EIA expansion through equatorial forests between 2,200 and 1,90о в $\mathrm{P}$ created major discontinuities in material culture from Cameroon to the DRC, resulting in smaller territories than during the preceding Neolithic.

The social mechanism responsible for the succeeding waves of expansion must have been complex, diverse and irregular. Social complexity is evident in the small cemeteries in the northwest (Cameroon, Equatorial Guinea and Gabon). It predates by several centuries what was to become the Kongo kingdom to the south and the Luba kingdom in the southeast (de Maret 1991, 1999, 2018). The emergence of inequalities in the northwest is worthy of further archaeological research. We suggest the smaller territories identified by the mapping of the various material cultures is linked to the development of local iron working, leading to the possibility of producing excess iron objects, some of them probably invested in symbolic value and deposited in the EIA cemeteries of Cameroon and Equatorial Guinea. The pottery groups regionalization must have been a side effect of the rise of social inequalities.

Overall, the pottery sequence from the earliest Neolithic villages to the Late Iron Age shows continuity of occupation at least for parts of Equatorial Guinea and Gabon. This continuity created a high degree of interaction between the cultural entities, leading to a high level of regional diversity. Within this continuity, we identify transitions in the material culture occurring after several centuries of stability; these radical changes in the production sequences are, we believe, evidence of new incoming people. The radiocarbon dates series for the transition from Neolithic to the Early Iron Age and later within the Iron Age show the new communities probably coexisted for some time with the preceding inhabitants before the former material culture disappeared. This is a picture we have seen for Gabon, but it is also known in Congo and in the western DRC.

Some 40 years ago, Jan Vansina correctly stated "new beginnings on limited portions of the Bantu question are required, rather than new paragdigms" (Vansina 1980: 313), a statement regrettably still true. More recently, it has been proposed the combination of historical Bantu linguistics, archaeology and molecular genetics had not significantly changed the overall preliminary picture of the past 3,000 years of history of Central Africa (Eggert 2016: 88). Maybe 
this Uppsala International Conference will become another starting point for this renewed research. But we are convinced, as Eggert before us (Eggert 2005: 322), that archaeology must develop its own set of transdisciplinary research, closely associating archaeology, paleo-ethnobotany, archaeozoology, geography, and ecology — amongst others — united within programs of intensive and systematic fieldwork and using its own agenda.

\section{References}

Asombang, R. 1988. Bamenda in prehistory: the evidence from Fiye Nkwi, Mbi Crater and Shum Laka rockshelters. Unpublished Ph.D. Thesis. London University: London, UK. Assoko Ndong, A. 1988. Recherches en traditions orales et en archéologie dans la province du Woleu-Ntem (Gabon), 1985-1987. Nsi 4: 10-20.

Assoko Ndong, A. 2001. Archéologie du peuplement Holocène de la réserve de faune de la Lopé, Gabon. Unpublished PhD Thesis. Université Libre de Bruxelles: Brussels, Belgium.

Assoko Ndong, A. 2002. Synthèse des données archéologiques récentes sur le peuplement à l'Holocène de la réserve de faune de la Lopé, Gabon. l'Anthropologie 106(1): $135^{-158 .}$

Assoko Ndong, A. 2003. Séquence archéologique et distribution des sites au nord de la réserve de faune de la Lopé (Gabon). In: Froment, A., and Guffroy, J. (eds) Peuplements anciens et actuels de des forêts tropicales, Actes du séminaire-atelier Orléans 15 -16 octobre 1998. IRD Editions, Collection Colloques et Séminaires: Paris, France, pp. 113-125.

Bayle des Hermens, R.de. 1975. Recherches préhistoriques en République Centrafricaine. Klincksieck: Paris, France.

Bayle des Hermens, R.de. 1984. L'art rupestre en République Centrafricaine. Bolletino del Centro Camuno di studi preistorici di Brescia 21: 75-84.

Bayle des Hermens, R.de, Clist, B., Peyrot, B., and Oslisly R. 1987. 'Premières séries de pierres taillées du Paléolithique Inférieur découvertes au Gabon, Afrique Centrale'. L'Anthropologie 91(2): 693-698.

Bostoen, K. 2006-07 (2010). Pearl millet in early Bantu speech communities in Central Africa: a reconsideration of the lexical evidence. Afrika und Übersee 89: 183-213.

Bostoen, K. 2007. Pots, words and the Bantu problem: on lexical reconstruction and early African history'. Journal of African History 48: 173-199.

Bostoen, K. 2018. The Bantu expansion. In: Oxford Research Encyclopedia of African History. Oxford University Press: Oxford, UK.

Bostoen, K., Clist, B., Doumenge, C., Grollemund, R., Hombert, J.-M., Koni Muluwa, J., and Maley J. 2015. Middle to Late Holocene Paleoclimatic Change and the Early Bantu Expansion in the Rain Forests of Western Central Africa. Current Anthropology $56(3): 354^{-384}$. 
Brémond, L., Bodin, S.C., Bentaleb, I., Favier, C., and Canal, S. 2017. Past tree cover of the Congo basin recovered by phytoliths and $d_{13} \mathrm{C}$ along soil profiles. Quaternary International 434: 91-101.

Brncic, T.M., Willis, K.J., Harris, D.J., and Washington, R. 2007. Culture or climate? The relative influences of past processes on the composition of the lowland Congo rainforest. Philosophical Transactions of the Royal Society, B Biological Sciences, 362: 229-242.

Brncic, T.M., Willis, K.J., Harris D.J., Telfer M.W., and Bailey, R.M. 20o9. Fire and climate change impacts on lowland forest composition in northern Congo during the last 2580 years from palaeoecological analyses of a seasonally flooded swamp. The Holocene, 19(1): 79-89.

Cahen, D. 1975. Le site archéologique de la Kamoa (région du Shaba, République du Zaïre) de l'âge de la pierre ancienne à l'âge du fer. Annales du Musée Royal de l'Afrique Centrale, Sciences Humaines, n84. Musée Royal de l'Afrique Centrale: Tervuren, Belgium.

Claes, P. 1985. Contribution à l'étude de céramiques anciennes des environs de Yaoundé. Unpublished MA Thesis. Université Libre de Bruxelles: Brussels, Belgium.

Clist, B. 1987a. A critical reappraisal of the chronological framework of Urewe Early Iron Age Industry. Muntu 6: 35-62.

Clist, B. 1987b. Travaux archéologiques récents en République du Gabon 1985-1986. Nsi 1: 9-12.

Clist, B. 1987 c. 1985 : fieldwork in Gabon. Nyame Akuma 28: 6-9.

Clist, B. 1988. Un nouvel ensemble néolithique en Afrique Centrale : le Groupe d'Okala au Gabon. Nsi 3: 43-51.

Clist, B. 1989a. Archaeology in Gabon, 1886-1988. The African Archaeological Review 7: 59-95.

Clist, B. 1989b. Bilan des premiers travaux du Département d'Archéologie du CICIBA: missions du premier semestre 1985. In: Obenga, Th. (ed) Actes du colloque international: Les peuples Bantu, migrations, expansion et identité culturelle, Libreville, 1-6 Avril 1985, volume 1. L'Harmattan/Cic IBA: Paris, France, pp. 103-110.

Clist, B. 1989c. Vestiges archéologiques de fontes du fer dans la province du WoleuNtem au Gabon. Nsi 6: 79-96.

Clist, B. 199o. Des derniers chasseurs aux premiers métallurgistes: sédentarisation et débuts de la métallurgie du fer (Cameroun, Guinée-Equatoriale, Gabon). In: Lanfranchi, R., and Schwartz, D. (eds) Paysages quaternaires de l'Afrique centrale atlantique. Paris: оRSt oм, Collection Didactiques: Paris, France, pp. 458-478.

Clist, B. 1991. L'Age du Fer ancien: Centrafrique. In: Lanfranchi, R., and Clist, B. (eds) Aux origines de l'Afrique Centrale. Ministère de la Coopération et du Développement, Centre Culturel français de Libreville, Sépia Editions: Paris, France, pp. 197-201.

Clist, B. 1993. Fouilles archéologiques de sites Age du Fer Récent dans la province du Woleu-Ntem entre 1985 et 1989. Revue Gabonaise des Sciences de l'Homme 3: 205-232. 
Clist, B. 1995a. Gabon : 100.00o ans d'Histoire. Centre Culturel français Saint-Exupéry, Sépia Editions: Paris, France.

Clist, B. 1995b. Archaeological work in Gabon during 1993 and 1994. Nyame Akuma 43: $18-21$.

Clist, B. 1997. Le site d'Okala, Province de l'Estuaire, Gabon et son importance pour la compréhension du passage à la sédentarisation en Afrique Centrale. Comptes rendus de l'Académie des Sciences de Paris, série Sciences de la Terre et des Planètes, 325: $151-156$.

Clist, B. 2005. Des premiers villages aux premiers européens autour de l'estuaire du Gabon : quatre millénaires d'interactions entre l'homme et son milieu. Unpublished PhD Thesis. Université Libre de Bruxelles: Brussels, Belgium.

Clist, B. 2006a. Mais où se sont taillées nos pierres en Afrique Centrale entre 7.000 et 2.000 bp? In: Wotzka, H.-P. (ed) Grundlegungen. Beiträge zur europäischen und afrikanischen Archäologie für Manfred K.H. Eggert. Francke Attempto Verlag GmbH and Co. KG: Tübingen, Germany, pp. 291-302.

Clist, B. 2006b. Coexistences matérielles entre 6000 et 20 cal BC en Afrique centrale : une mosaïque culturelle. In: Astruc, L., Bon F., Lea V., Milcent, P.-Y., and Phillibert, S. (eds) Normes techniques et pratiques sociales. De la simplicité des outillages préet protohistoriques (XXVIe rencontres internationales d'archéologie et d'histoire d'Antibes), Editions APDCA: Antibes, France, pp. 377-383.

Clist, B. 2006c. Mise en évidence dans le nord-ouest du Gabon de la présence de l'homme au sein des forêts d'âge Holocène. Journal of African Archaeology 4(1): 143-152.

Clist, B. 2012. Vers une réduction des préjugés et la fonte des antagonismes: un bilan de l'expansion de la métallurgie du fer en Afrique sud-saharienne. Journal of African Archaeology 10(1): 71-84.

Clist, B. 2013. Our iron smelting ${ }_{14} \mathrm{C}$ dates from Central Africa: from a plain appointment to a full blown relationship. In: Humphris, J., and Rehren, T. (eds) The World of Iron. Archetype Publications: London, UK, pp. 22-28.

Clist, B. 2018. Les pipes en terre cuite et en pierre. In: Clist, B., de Maret, P., and Bostoen, K. (eds) Une archéologie des provinces septentrionales du royaume Kongo. Archaeopress: Oxford, UK, pp. 297-327.

Clist, B. 2020. Guinea Ecuatorial: más de 40.000 años de Historia reveladas por la arqueología. L'Harmattan: Paris, France.

Clist, B., Béarez, Ph., Mougne, C., Lesur, J., Murungi, M., Hubau, W., Griepentrog, M., Baert, G., Vermeir, P., Boeckx, P., Van Nieuland, K., Bamford, M., and Bostoen, K. Forthcoming. Multi-proxy assessment of material culture, subsistence and environment at an Early Iron Age coastal site in Muanda (Kongo Central Province, Democratic Republic of Congo. The African Archaeological Review.

Clist, B., Bigohe, S., Mambu, C., and Bostoen, K. 2018. The BantuFirst Project: 2018 Fieldwork Report from the Kongo Central Province of the Democratic Republic of the Congo. Nyame Akuma 9o: 14-22. 
Clist, B., de Maret, P., and Bostoen, K. (eds). 2018a. Une archéologie des provinces septentrionales du royaume Kongo. Archaeopress: Oxford, UK.

Clist, B., de Maret, P., and Bostoen, K. 2018b. L'histoire du royaume Kongo revisitée par l'archéologie. In: Clist, B., de Maret, P., and Bostoen, K. (eds) Une archéologie des provinces septentrionales du royaume Kongo. Archaeopress: Oxford, UK, pp. 443-453.

Clist, B., Hubau, W., Tshibamba Mukendi, J., Beeckman, H., and Bostoen, K. 2019. The earliest iron-producing communities in the Lower Congo region of Central Africa: New insights from the Bu, Kindu and Mantsetsi sites. Azania: Archaeological Research in Africa 2: 221-244.

Clist, B., and Jézégou, M.-P. 1991. Le néolithique: Gabon. In: Lanfranchi, R., and Clist, B. (eds) Aux origines de l'Afrique Centrale. Ministère de la Coopération et du Développement, Centre Culturel français de Libreville, Sépia Editions: Paris, France, pp. 165-170.

Cornelissen, E. 1997. Central African transitional cultures. In: Vogel, J. (ed) Encyclopedia of precolonial Africa. AltaMira Press: Walnut Creek-London-New Delhi, USA UK - India, pp. 312-320.

Cornelissen, E. 2016. The Later Pleistocene in the Northeastern Central African Rainforest. In:Jones, S.C., and Stewart, B.A. (eds) Africa from MIS 6-2: Population Dynamics and Paleoenvironments. Springer: Dordrecht, Netherlands, pp. 301-319.

Crevecoeur, I., Brooks, A., Ribot, I., Cornelissen, E., and Semal, P. 2016. Late Stone Age human remains from Ishango (Democratic Republic of Congo): New insights on Late Pleistocene modern human diversity in Africa. Journal of Human Evolution 96: $35^{-57 .}$

de Maret, P. 1982. Rock art. In: Van Noten, F. (ed) The archaeology of Central Africa. Akademische Drück, und Verlagsantstalt: Graz, Austria, pp. 97-99.

de Maret, P. 1986. The Ngovo group : an industry with polished stone tools and pottery in lower Zaïre. The African Archaeological Review 4: 103-133.

de Maret, P. 1989. Le contexte archéologique de l'expansion Bantu en Afrique Centrale. In Obenga, Th. (ed) Les peuples Bantu : migrations, expansion et identité culturelle, volume 1. l'Harmattan ; Paris, France, pp. 118-138.

de Maret, P. 1991. L'archéologie du royaume Luba. In: Lanfranchi, R., and Clist, B. (eds) Aux origines de l'Afrique centrale. Centres Culturels Français de l'Afrique Centrale / Sépia: Paris, France, pp. 234-241.

de Maret, P. 1999. The power of symbols and the symbols of power through time : probing the Luba past. In: McIntosh, S. (ed) Beyond chiefdoms : pathways to complexity in Africa, Cambridge University Press: Cambridge, UK, pp. 131-165.

de Maret, P. 2012. From Kinship to Kingship: An African journey into complexity". Azania: Archaeological Research in Africa 47(3): 314-326.

de Maret, P. 2013. Archaeologies of the Bantu expansion. In: Mitchell, P., and Lane, P. (eds) The Oxford handbook of African archaeology. Oxford University Press: Oxford, UK, pp. 627-643. 
de Maret, P. 2018. Les royaumes Kongo et Luba, cultures et sociétés dans le bassin du Congo. In: Fauvelle, F.X. (ed) De l'Acacus au Zimbabwe, 20.000 avant notre ère-XVIIe siècle. Belin: Paris, France, pp. 311-341.

de Maret, P., Clist, B., and Bostoen, K. 2018. Regards croisés sur le royaume Kongo. In: Clist, B., de Maret, P., and Bostoen, K. (eds) Une archéologie des provinces septentrionales du royaume Kongo. Archaeopress: Oxford, UK, pp. 455-46o.

de Maret, P., Clist, B., and Van Neer. W. 1987. Résultats des premières fouilles dans les abris-sous-roche de Shum Laka et Abeke au Nord-Ouest du Cameroun. L'Anthropologie $91(2): 559-584$.

de Maret, P., and Nsukka F. 1977. History of Bantu metallurgy: some linguistic aspects. History in Africa 4: 43-65.

Denbow, J. 2014. The archaeology and ethnography of Central Africa. Cambridge University Press: Cambridge, UK.

de Saulieu, G., Ngouoh, F., and Oslisly, R. 2015. Lâge du Fer ancien dans le bloc forestier du sud Cameroun: nouvelles données entre Sangmélima et Mintom. Azania: Archaeological Research in Africa, 5O(3): 402-417.

de Saulieu, G., Oslisly, R., Nlend, P., and Ngouoh, F. 2017. Deux mille cinq cents ans de traditions céramiques à Dibamba Yassa (Cameroun)". Afrique : Archéologie \& Arts, 13 : https://aaa.revues.org/979.

Dupont, L.M., Behling, H., and Jung-Hyun Kim, K. 2008. Thirty thousand years of vegetation development and climate change in Angola (Ocean Drilling Program Site 1078). Climate Past 4: 107-124.

Dupré, M.-C., and Pinçon, B. 1997. Métallurgie et politique en Afrique Centrale, deux mille ans de vestiges sur les plateaux bateke (Gabon, Congo, Zaïre). Khartala: Paris, France.

Eggert, M.K.H. 1987. Imbonga and Batalimo : ceramic evidence for early settlement of the equatorial rain forest. The African Archaoelogical Review 5: 129-145.

Eggert, M.K.H. 1994-1995. Pots, farming and analogy: Early ceramics in the equatorial rainforest. Azania: Archaeological Research in Africa XXIX-XXX: 332-338.

Eggert, M.K.H. 2002. Southern Cameroon and the settlement of equatorial rainforest : early ceramics from fieldwork in 1997 and 1998-1999. Africa Praehistorica 14: 507-522.

Eggert, M.K.H. 2005. The Bantu Problem and African Archaeology. In: Stahl, A. (ed) African Archaeology: A Critical Introduction (Blackwell Studies in Global Archaeology). Blackwell Publishing: London, UK, pp. 301-326.

Eggert, M.K.H. 2014. Early Iron in West and Central Africa. In: Breunig, P. (ed) Nok, African Sculpture in Archaeological context. Afrika Magna Verlag: Frankfurt-amMain, Germany, pp. 51-59.

Eggert, M.K.H. 2016. Geneticizing Bantu: Historical insight or historical trilemma?'. Medieval Worlds 6: 79-9o.

Eggert, M.K.H., and Seidensticker, D. 2016. Campo: archaeological research at the mouth of the Ntem river (South Cameroon). Heinrich Barth Institut: Köln, Germany. 
Eggert, M.K.H., Höhn, A., Kahlheber, S., Meister, C., Neumann, K., and Schweizer, A. 2006. Pits, graves, and grains : archaeological and archaeobotanical research in southern Cameroon. Journal of African Archaeology 4(2): 273-298.

Ehret, C. 2015. Bantu history: Big advance, although with a chronological contradiction, Proceedings of the National Academy of Sciences of the USA 112(44):13428-13429.

Ervedosa, C. 1980. Arqueologia Angolana. Ministerio da Educaçao, República Popular de Angola: Lisboa, Portugal.

Fuller, D.Q., Nixon, S., Stevens, C., and Murray, M.A. 2014. African Archaeobotany Expanding: an editorial. In: Stevens, C., Nixon, S., Murray, M.A., and Fuller, D.Q. (eds) Archaeology of African Plant Use. Left Coast Press: Walnut Creek, USA, pp. 17-24.

Giresse, P., Maley, J., and Chepstow-Lusty, A. 2020, Understanding the 2500 yr BP rainforest crisis in West and Central Africa in the framework of the Late Holocene: Pluridisciplinary analysis and multiarchive reconstruction, Global and Planetary Change, 192, September 2020.

Gonzalez-Ruibal, A., Picornell Gelabert, L., and Valenciano Mane, A. 2011. Early Iron Age burials from Equatorial Guinea : the sites of Corisco Island. Journal of African Archaeology 9(1): 41-66.

Gonzalez-Ruibal, A., Sanchez-Elipe, M., and Otero-Vilarino, C. 2013. An ancient and common tradition: funerary rituals and society in Equatorial Guinea (first-twelth centuries AD ). African Archaeological Review 30(2): 115-143.

Grollemund, R., Branford, S., Bostoen, K., Meade, A., Venditti, C., and Pagel, M. 2015. Bantu expansion shows that habitat alters the route and pace of human dispersals. Proceedings of the National Academy of Sciences of the USA 112(43): 13296-13301.

Gutierrez, M. 1996. L'art pariétal de l'Angola. L'Harmattan: Paris, France.

Heimlich, G. 2017. Le massif de Lovo, sur les traces du royaume de Kongo. Cambridge Monographs in African Archaeology n${ }^{\circ}$ 5. ArchaeoPress: Oxford, UK.

Hiernaux, J., and Maquet, E. 196o. Cultures préhistoriques de l'âge des métaux au Randa-Urundi et au Kivu (Congo Belge), zème partie. Suivi de deux sites archéologiques à briques en territoire Walikale (Kivu), Mémoire de la Classe des Sciences Naturelles et Médicales, Nouvelle série, tome X, fascicule 2. Académie Royale des Sciences d`Outre-Mer: Brussels, Belgium.

Jézégou, P.P., and Clist, B. 1991. L’Age du Fer Ancien: Gabon. In: Lanfranchi, R., and Clist, B. (eds) Aux origines de l'Afrique Centrale. Ministère de la Coopération et du Développement, Centre Culturel français de Libreville, Sépia Editions: Paris, France, pp. 202-2O7.

Kahlheber, S., Höhn, A., and Neumann, K. 2014. Plant and land use in Southern Cameroon 400 BCE - 400 CE. In: Stevens, C.J., Nixon, S., Murray, M.A., and Fuller, D. (eds) Archaeology of African Plant Use. Left Coast Press: Walnut Creek, pp. 113-128.

Kiahtipes, C.A. 2016. Late Holocene Paleoenvironments and Anthropogenic Impacts in the Ngotto Forest, Central African Republic. Unpublished PhD Thesis. Southern Methodist University: Texas, USA. 
Lanfranchi, R. 1985. Note sur les abris ornés de la région de Bouansa. Cataractes 1:123-131. Lanfranchi, R. 1991a. Synthèse régionale de l'Age de la Pierre Récent. In: Lanfranchi, R., and Clist, B. (eds) Aux origines de l'Afrique Centrale. Ministère de la Coopération et du Développement, Centre Culturel français de Libreville, Sépia Editions: Paris, France, pp. 127-128.

Lanfranchi, R. 1991b. Néolithique: Congo. In: Lanfranchi, R., and Clist, B. (eds) Aux origines de l'Afrique Centrale. Ministère de la Coopération et du Développement, Centre Culturel français de Libreville, Sépia Editions: Paris, France, pp. 171-173.

Lanfranchi, R., and Clist, B. (eds). 1991. Aux origines de l'Afrique Centrale. Ministère de la Coopération et du Développement, Centre Culturel français de Libreville, Sépia Editions: Paris, France.

Lanfranchi, R., and Schwartz, D. (eds). 199o. Paysages quaternaires de l'Afrique centrale atlantique, Collection Didactiques. ORSTOM: Paris, France.

Lavachery, Ph. 1996. Shum Laka rock shelter late Holocene deposits : from stone to metal (north western Cameroon). In: Pwiti, G., and Soper, R. (eds) Aspects of african archaeology, Papers from the 1oth PanAfrican Association for prehistory and Related Studies Congress, Harare. University of Zimbawe Publication: Harare, pp. 266-274.

Lavachery, P. 1998. De la pierre au métal. Archéologie des dépôts holocènes de l'abri sous roche de Shum Laka (Cameroun). Unpublished $\mathrm{PhD}$ Thesis. Université Libre de Bruxelles: Brussels, Belgium.

Lavachery, Ph. 2001. The Holocene archaeological sequence of Shum Laka rock shelter (Grassfields, western Cameroon). The African Archaeological Review 18(4): pp. $213^{-247}$.

Lavachery, Ph. 2003. A la lisière de la forêt : 10.000 ans d'interactions entre l'homme et l'environnement dans les Grassfields (Cameroun). In: Froment, A., and Guffroy, J. (eds) Peuplements anciens et actuels de des forêts tropicales (Actes du séminaire-atelier Orléans 15-16 octobre 1998). IRD Editions: Paris, France, pp. 89-102.

Lavachery, Ph., and Cornelissen, E. 20oo. Natural and Cultural Spatial Patterning in the Late Holocene Deposits of Shum Laka Rock Shelter, Cameroon. Journal of Field Archaeology, 27(2): 153-158.

Lavachery, Ph., Cornelissen, E., Moeyersons, J., and de Maret, P. 1996. 30.00o ans d'occupation, 6 mois de fouilles : Shum Laka, un site exceptionnel en Afrique centrale. Anthropologie et Préhistoire 107: 197-211.

Lavachery, Ph., Maceachern, S., Tchago, B., Gouem Gouem, B., Kinyock, P., Mbairo, J., and Nkonkonda, O. 2005. Komé to Ebomé: Archaeological Research for the Chad Export Project, 1999-2003. Journal of African Archaeology 3(2): 175-193.

Lébamba, J., Vincens, A., and Maley, J. 2012. Pollen, vegetation change and climate at Lake Barombi Mbo (Cameroon) during the last ca. 33 oоo cal yr вP: A numerical approach. Climate Past 8: 59-78. 
Lézine, A.-M., and Cazet, J.-P. 2005. High-resolution pollen record from core KW31, Gulf of Guinea, documents the history of the lowland forests of West Equatorial Africa since 40 ooo yr ago. Quaternary Research 64: 432-443.

Lézine, A.-M., Izumi Kenji, Masa, K., and Achoundong, A. 2019. A 90,ooo-year record of Afromontane forest responses to climate change. Science 363: 177-181.

Linseele, V. 2018. Les ossements d'animaux. In: Clist, B., de Maret, P., and Bostoen, K. (eds) Une archéologie des provinces septentrionales du royaume Kongo. Archaeopress: Oxford, UK, pp. 439-440.

Lipson, M., Ribot, I., Mallick, S., Rohland, N., Olalde, I., Adamski, N., Broomandkhoshbacht, N., Lawson, A.M., López, S., Oppenheimer, J., Stewardson, K., Asombang, R., Bocherens, H., Bradman, N., Culleton, B.J., Cornelissen, E., Crevecoeur, I., de Maret, P., Fomine, F.L.M., Lavachery, Ph., Mbida, Ch., Orban, R., Sawchuk, E., Semal, P., Thomas, M.G., Van Neer, W., Veeramah, K.R., Kennett, D.J., Patterson, N., Hellenthal, G., Lalueza-Fox, C., Maceachern, S., Prendergast, M.E., and Reich, D. 202O. Ancient West African foragers in the context of African population history, Nature 577: 665-670.

Livingstone-Smith, A. 2007. Histoire du décor à la roulette en Afrique subsaharienne. Journal of African Archaeology 5(2):189-216.

Livingstone-Smith, A., Assoko Ndong, A., and Cornelissen, E. 2007. Prospection archéologique dans le sud du Gabon. Nyame Akuma 67: 26-35.

Livingstone-Smith, A., Cornelissen, E., De Francquen, C., Nikis, N., Mees, F., Tshibamba Mukendi, J., Beeckman, H., Bourland, N., and Hubau, W. 2017. Forests and rivers: The archaeology of the north eastern Congo. Quaternary International 448: 95-116.

Locko, M. 1991a. Ages de la Pierre Ancien et Moyen: Gabon. In: Lanfranchi, R., and Clist, B. (eds) Aux origines de l'Afrique Centrale. Ministère de la Coopération et du Développement, Centre Culturel français de Libreville, Sépia Editions: Paris, France, pp. 66-70.

Locko, M. 1991b. 'Age de la Pierre Récent: Gabon. In: Lanfranchi, R., and Clist, B. (eds) Aux origines de l'Afrique Centrale. Ministère de la Coopération et du Développement, Centre Culturel français de Libreville, Sépia Editions: Paris, France, pp. 107-110.

Lopez, M., Choin, J., Sikora, M., Siddle, K., Harmant, C., Costa, H.A., Silvert, M., Mouguiama-Daouda, P., Hombert, J.-M., Froment, A., Le Bomin, S., Perry, G.H., Barreiro, L.B., Bustamante, C.D., Verdu, P., Patin, E., and Quintana-Murci, L. 2019. Genomic evidence for local adaptation of hunter-gatherers to the African rainforest. Current Biology 29: 1-10.

Loumpet-Galitzine, A. 1992. Approche synthétique de l'art rupestre d'Afrique Centrale. l'Anthropologie 96: 759-768.

Loumpet-Galitzine, A. 1998. Art rupestre du Cameroun : état des connaissances et réflexions méthodologiques. In: Delneuf, M., Essomba, J.-M., and Froment, A. (eds) Paléo-anthropologie en Afrique centrale. Un bilan de l'archéologie au Cameroun. L'Harmattan: Paris, France. pp. 157-187. 
Lupo, K.D., Schmitt, D.N., Ndanga, J-P., Nguerede, L.P., Amaye, G.T., Livingstone Smith, A., Edwards, N.M., Power, R.C., Young, D.C., and Npo, F. 2021, Hunter-gatherers on the basin's edge: a preliminary look at Holocene human occupation of Nangara-Komba Shelter, Central African Republic. Azania: Archaeological Research in Africa, 56. Published online: 13 Jan 2021.

Maley, J. 1987. Fragmentation de la forêt dense humide africaine et extension des biotopes montagnards au Quaternaire récent: nouvelles données polliniques et chronologiques. Implications paléoclimatiques et biogéographiques. In: Coetzee, J.A. (ed) Palaeoecology of Africa and the surrounding islands, 18. A.A. Balkema: Rotterdam-Brookfield, Netherlands - USA, pp. 307-334.

Maley, J., and Brenac, P. 1998. Vegetation dynamics, palaeoenvironments and climatic changes in the forests of western Cameroon during the last 28, ooo years BP. Review of Palaeobotany and Palynology 99: 157-187.

Maley, J., Doumenge, C., Giresse, P., Mahé, G., Philippon, N., Hubau, W., Lokonda, M., Tshibamba J.M., and Chepstow-Lusty, A. 2018. Late Holocene forest contraction and fragmentation in central Africa. Quaternary Research 89(1): 43-59.

Marchal-Nasse, C. 1991. Les Bantu, entité linguistique. In: Lanfranchi, R., and Clist, B. (eds) Aux origines de l'Afrique Centrale. Ministère de la Coopération et du Développement, Centre Culturel français de Libreville, Sépia Editions: Paris, France, pp. 134-143.

Martin del Molino, A. 1965. Secuencia cultural en el neolitico de Fernando Poo. Trabajos de Preistoria del Seminario de Historia Primitiva del Hombre del Universidad de Madrid y del Instituto Espanol de Prehistoria del Consejo Superior de Investigaciones Cientificas, $\mathrm{n}^{\circ} 17$, Madrid, Spain.

Martins, C.P. 2014. The rock art of Angola within its context. In: Osterbeek, L., Camara, A., and Martins, C.P. (eds) Archaeology, Societies and Environments in Africa. British Archaeological Reports, International Series n ${ }^{\circ} 2655$ : Oxford, UK, pp. 21-28.

Mbida Minzie, C. 1996. L'émergence des communautés villageoises au Cameroun méridional. Etude archéologique des sites de Nkang et de Ndindan. Unpublished PhD Thesis. Université Libre de Bruxelles: Brussels, Belgium.

Mbida Minzie, C. 2003. Essai d'interprétation spatiale des sites à fosses du sud-Cameroun : hypothèses et spéculations. In: Froment, A., and Guffroy, J. (eds) Peuplements anciens et actuels de des forêts tropicales, Actes du séminaire-atelier Orléans 15-16 octobre 1998. IRD Editions, Collection Colloques et Séminaires: Paris, France, pp. 103-112.

McIntosh, S.K. (ed). 1999. Beyond Chiefdoms: Pathways to Complexity in Africa. Cambridge University Press: Cambridge, UK.

Meister, C. 2008. Recent archaeological investigations in the tropical rain forest of South-West Cameroon. In: Runge, J. (ed) Dynamics of forest ecosystems in Central Africa during the Holocene: past, present, future (Palaeoecology of Africa, volume 28). Taylor \& Francis: London \& New-York, UK \& USA, pp. 43-57. 
Meister, C. 2010. Remarks on Early Iron Age burial sites from Southern Cameroon. African Archaeological Review 27: 237-249.

Meister, C., and Eggert, M.K.H. 20o8. On the Early Iron Age in Southern Cameroon: the sites of Akonetye. Journal of African Archaeology 6(2): 183-202.

Mercader, J., Rovira, S., and Gomez, P. 200o. Shared technologies : Later Stone Age forager-farmer interaction and ancient iron metallurgy in the Ituri rainforest, Democratic Republic of Congo. Azania: Archaeological Research in Africa 35: 107-122.

Mercader, J., Garralda, M.D., Pearson, O., and Bailey, R. 2001. 800 year old human remains from the tropical forest of Ituri, Democratic Republic of Congo : the rock shelter site of Matangai Turu Northwest. American Journal of Physical Anthropology 115: 24-37.

Mercader, J., Marti, R., Martinez, J.L., and Brooks, A. 2002. The nature of stone-lines in the African Quaternary record : archaeological resolution at the rainforest site of Mosumu, Equatorial Guinea. Quaternary International 89: 71-96.

Merlet, A. 1990. Le pays des trois estuaires (1471-1900). Quatre siècles de relations extérieures dans les estuaires du Muni, de la Mondah et du Gabon. Centre Culturel français Saint Exupéry, Sépia Editions: Paris, France.

Meye Medou, F. 199o. Nouvelles prospections archéologiques dans la province du Woleu-Ntem au Gabon de 1987 à 1989. Nsi 7: 26-32.

Mongolo Mololi, N. 2012. Létude de l'art rupestre au Congo : Première approche. Unpublished ma Thesis ('Mémoire de Master 1'). Université de Paris I: Paris, France.

Mongolo Mololi, N. 2013. Létude de l'art rupestre au Congo : cas de la Bouenza. Unpublished MA Thesis ('Mémoire de Master 2'). Université de Paris I: Paris, France.

Morin-Rivat, J., Fayolle, A., Gillet, J.-F., Bourland, N., Gourlet-Fleury, S., Oslisly, R., Brémond, L., Bentaleb, I., Beeckman, H., and Doucet, J.-L. 2014. New evidence of human activities during the Holocene in the lowland forests of the northern Congo Basin. Radiocarbon 56, 1: 209-220.

Morin-Rivat, J., Biwolé, A., Gorel, A.-P., Vleminckx, J., Gillet, J.-F., Bourland, N., Hardy, O.J., Livingstone-Smith, A., Daïnou, K., Dedry Laurent, Beeckman Hans and JeanLuis Doucet. 2016. High spatial resolution of late-Holocene human activities in the moist forests of central Africa using soil charcoal and charred botanical remains. The Holocene 26 (12): 1954-1967.

Mortelmans, G. 1952. Les dessins rupestres gravés ponctués et peints du Katanga : essai de synthèse. Annales du Musée Royal du Congo Belge, Science de l'Homme, Préhistoire, I. Musée Royal de l'Afrique Centrale: Tervuren, Belgium.

Muya Wa Bitanko Kamuanga, D. 1991a. Ages de la Pierre Ancien et Moyen : Zaïre. In: Lanfranchi, R., and Clist, B. (eds) Aux origines de l'Afrique Centrale. Ministère de la Coopération et du Développement, Centre Culturel français de Libreville, Sépia Editions: Paris, France, pp. $75^{-81 .}$

Muya Wa Bitanko Kamuanga, D. 1991b. Age de la Pierre Récent : Zaïre. In: Lanfranchi, R., and Clist, B. (eds) Aux origines de l'Afrique Centrale. Ministère de la Coopération 
et du Développement, Centre Culturel français de Libreville, Sépia Editions: Paris, France, pp. 115-122.

Ndanga, A., Amaye, G., and Weelhouse, P. 2013a. Rapport de la mission d'archéologie préventive de la mine de Mayoko. Unpublished Report, CURDHACA, Université de Bangui, Bangui, Central African Republic.

Ndanga, A., Nguerede, L., Amaye, G., Weelhouse, P., and Hobson, A. 2013b. Rapport des fouilles archéologiques du permis minier d'Exxaro à Mayoko en République du Congo (6 Septembre- 2 Novembre 2013). Unpublished Report, CURDHACA, Université de Bangui: Bangui, Central African Republic.

Neumann, K. 2018. Development of plant food production in the West African savannas: archaeobotanical perspectives". In: Oxford Research Encyclopedia of African History. Oxford University Press: Oxford, UK.

Neumann, K., Bostoen, K., Höhn, A., Kahlheber, S., Ngomanda, A., and Tchiengue, B. 2012. First farmers in the Central African rainforest: a view from southern Cameroon. Quaternary International 249: 53-62.

Ngomanda, A., Chepstow-Lusty, A., Makaya Mvoubou, Schevin, P., Maley, J., Fontugne, M., Oslisly, R., Rabenkogo, N., and Jolly, J. 2005. Vegetation changes during the last 1300 years in Western Equatorial Africa, a high-resolution pollen record from Lake Kamalete, Lope Reserve, Central Gabon. The Holocene 15(7): 1021-1031.

Ngomanda, A., Jolly, D., Bentaleb, I., Chepstow-Lusty, A., Makaya Mvoubou, Maley, J., Fontugne M., Oslisly, R., and Rabenkogo, N. 2007. Lowland rainforest response to hydrologic changes during the last 1500 years in Gabon, Western Equatorial Africa. Quaternary research 67, 3: 411-425.

Nlend Nlend, P. 2014. Les traditions céramiques dans leur contexte archéologique sur le littoral camerounais (Kribi-Campo) de 3000 à 500 BP. Unpublished $\mathrm{PhD}$ Thesis. Université Libre de Bruxelles: Brussels, Belgium.

Nsuka-Nkutsi, F., and de Maret, P. 1982. Etude comparative de quelques termes métallurgiques dans les langues bantoues. In: Hyman, L.M., Voorhoeve, J., and Bouquiaux, L. (eds) L'Expansion bantoue: actes du Colloque international du CNRS, Viviers (France), 4-16 avril 1977, volume 3. SELAF: Paris, France, pp. 371-442.

Oslisly, R. 1986. Archéologie des enclaves savanicoles du Moyen Ogooué. Unpublished DEA Thesis. Université de Paris I: Paris, France.

Oslisly, R. 1992. Préhistoire de la moyenne vallée de l'Ogooué (Gabon). Unpublished PhD Thesis. Université de Paris I: Paris, France.

Oslisly, R. 2016. Signes sans paroles. Les gravures rupestres de la vallée de l'Ogooué. Gabon Magazine 29: 66-76.

Oslisly, R., and Assoko Ndong, A. 2006. Archéologie de sauvetage sur la route Médoumane-Lalara, vallée de l'Okano, Gabon. Wildlife Conservation Society: Libreville, Gabon.

Oslisly, R., and Peyrot, B. 1993. Les gravures rupestres de la vallée de l'Ogooué (Gabon). Editions Sépia: Paris, France. 
Perramon Marti, R. 1968. Contribucion a la prehistoria y protohistoria de Rio Muni. Instituto claretiano de Africanistas: Santa Isabel de Fernando Poo.

Peyrot, B., Clist, B., and Oslisly, R. 199o. Le gisement des «Sablières» de Libreville: étude géomorphologique et archéologique d'un site préhistorique de l'Estuaire du Gabon. L'Anthropologie, 94(3): 483-498.

Ribot, I., Orban, R., and de Maret, P. 2001. The prehistoric burials of Shum Laka rockshelter (Northwest Cameroon). Annales de Sciences Humaines, $\mathrm{n}^{\circ}{ }^{164}$. Musée Royal de l'Afrique Centrale: Tervuren, Belgium.

Rosina, P., Oosterbeek, L., Pombares Martins, C., and Gomes, H. 2018. Dating and Raman spectroscopy of rock art paintings in Ebo, Angola. Azania: Archaeological Research in Africa 53(1): 83-97.

Sánchez-Elipe Lorente, M. 2015. Las comunidades de la eda del hierro en África Centro-Occidental: cultura material e identidad. Unpublished PhD Thesis. Universidad Complutense de Madrid: Madrid, Spain.

Sánchez-Elipe Lorente, M., Gonzalez-Ruibal, A., Jorda Pardo, J.F., and Marin Suarez, C. 2016. The Iron Age in West Central Africa: radiocarbon dates from Corisco Island (Equatorial Guinea).Journal of African History 57(3): 345-365.

Santos Junior J.R. Dos and Ervedosa, C. 1970. A estaçâo arqueologica de Benfica, Luanda, Angola. Ciêncas biologicas 1(2): 33-51.

Sarrazin, O. 1987. Cibadate : fichier des datations absolues. Nsi 1: 39-41.

Schmidt, P.R., and Asombang, R.N. 1990. Archaeological survey in northwestern Cameroon. Nyame Akuma 34: 10-17.

Schwartz, D. 1991. Les paysages de l'Afrique centrale pendant le Quaternaire. In: Lanfranchi, R., and Clist, B. (eds) Aux origines de l'Afrique Centrale. Ministère de la Coopération et du Développement, Centre Culturel français de Libreville, Sépia Editions: Paris, France, pp. 41-45.

Schwartz, D. 1992. Assèchement climatique vers 3 ooo B.P. et expansion Bantu en Afrique centrale atlantique : quelques réflexions. Bulletin de la Société Géologique de France, $163(3): 353-361$.

Schwartz, D., Vincens, A., Elenga, H., Alexandre, A., Bertaux, J., Servant, M., Servant, S., Nguetsop F., Bonvallot, J., Guillet, B., Mariotti, A., De Namur, Ch., Reynaud-Farrera, I., Youta Happi J., Delègue, M.-A., Fuhr, M. \& les membres du programme Ecofit. 200o. Réponse des végétations d'Afrique Centrale atlantique (Congo, Cameroun) aux changements climatiques depuis l'Holocène moyen : pas de temps, variabilité spatiale. In: Barrué-Pastor, M., and Bertrand, G. (eds) Le temps de l'environnement. Presses Universitaires du Mirail: Toulouse, France, pp. 461-471.

Seidensticker, D. 2016. Archaeological Studies on Iron Age Settlement History in the Northwestern Congo Basin. In: Sadr, K., Esterhuysen, A., and Sievers, C. (eds) African archaeology without frontiers. Witwatersrand University Press: Johannesburg, South Africa, pp. 114-126. 
Taylor, N. 2014. Central and West African Middle Stone Age: Geography and Culture. In: Smith, C. (ed) Encyclopedia of Global Archaeology. Springer: New-York, USA, pp. 1208-1227.

Taylor, N. 2016. Across rainforests and woodlands: a systematic reappraisal of the Lupemban Middle Stone Age in Central Africa. In: Jones, S.C., and Stewart, B.A. (eds) Africa from MIS 6-2: Population Dynamics and Paleoenvironments, Springer: Dordrecht, Netherlands, pp. 273-299.

Tchandeu, N.S. 2016. Rock art in Cameroon: knowledge, new discoveries and contribution to the sub-regional iconography. In: Sadr, K., Esterhuysen, A., and Sievers, C. (eds) African archaeology without frontiers. Witwatersrand University Press: Johannesburg, South Africa, pp. 85-113.

Tessman, G. 1923. Die Pangwé. Volkerkundliche Monographie eines West-Afrikanischen Negerstammes, Berlin, Germany.

Tovar, C., Harris, D.J., Breman, E., Brncic, T., and Willis, K.J. 2019. Tropical monodominant forest resilience to climate change in Central Africa: A Gilbertiodendron dewevrei forest pollen record over the past 2,700 years. Journal of Vegetation Science 30: 575-586. https://doi.org/10.1111/jvs.12746.

Valdeyron, N., and Da Silva Domingos, S. 2009. Nouvelles données sur la préhistoire récente angolaise : le gisement de Cabolombo à Benfica revisité. In: De Méditerranée et d'ailleurs. Mélanges offerts à Jean Guilaine. Archives d'Ecologie Préhistorique: Toulouse, France, pp. 737-749.

Valdeyron, N., and Da Silva Domingos, S. 2012. Coquillages (beaucoup) et crustacés (un peu) : l'économie des populations littorales de la baie de Luanda (Angola), du début de notre ère jusqu'à la période actuelle. In: Palethnologie de l'Afrique, @lethnologie 4: 111-142.

Van Neer, W. 199o. Les faunes de vertébrés quaternaires en Afrique centrale. In: Lanfranchi, R., and Schwartz, D. (eds) 1990. Paysages quaternaires de l'Afrique centrale atlantique, Collection Didactiques. оRsт ом: Paris, France, pp. 195-220.

Van Neer, W. 1991. Les faunes quaternaires de l'Afrique centrale. In: Lanfranchi, R., and Clist, B. (eds) Aux origines de l'Afrique Centrale. Ministère de la Coopération et du Développement, Centre Culturel français de Libreville, Sépia Editions: Paris, France, pp. 47-51.

Van Neer, W. 200o. Domestic animals from archaeological sites in Central and West-Central Africa. In: Blench, R., and MacDonald, K. (eds) The origins and development of african livestock. UCL Press: London, UK, pp. 163-19o.

Van Neer, W., and Clist, B. 1991. Le site de l'Age du Fer Ancien d'Oveng (province de l'Estuaire, Gabon), analyse de sa faune et de son importance pour la problématique de l'expansion des locuteurs Bantu en Afrique Centrale. Comptes-rendus de l'Académie des Sciences de Paris 312(série II): 105-110.

Van Neer, W., and Lanfranchi, R. 1985. Etude de la faune découverte dans l'abri Tshitolien de Ntadi Yomba (R.P. du Congo). l'Anthropologie 89(3): 351-364. 
Van Noten, F. 1982. Introduction. In: Van Noten (ed) The archaeology of Central Africa. Akademische Drück- und Verlagsantstalt: Graz, Austria, pp. 11-13.

Vansina, J. 1980. Bantu in the crystal ball II. History in Africa 7: 293-325.

Vansina, J. 1990. Paths in the rainforest : toward a history of political tradition in Equatorial Africa. University of Wisconsin Press: Madison, USA.

Vansina, J. 1999. Pathways of political development in equatorial Africa and enoevolutionary theory. In: McIntosh, S. (ed) Beyond chiefdoms : pathways to complexity in Africa. Cambridge University Press: Cambridge, UK, pp. 166-172.

Vansina, J. 2006. Linguistic Evidence for the Introduction of Ironworking into Bantu-Speaking Africa. History in Africa 33: 321-361.

Verdu, P., Austerlitz, F., Estoup, A., Vitalis, R., Georges, M., Théry, S., Froment, A., Le Bomin, S., Gessain, A., Hombert, J.-M., Van der Veen, L., Quintana-Murci, L., Bahuchet, S., and Heyer, E. 2009. Origins and genetic diversity of pygmy hunter-gatherers from Western Central Africa, Current Biology 19: 312-318.

Von Morgen, C. 1893. Durch Kamerun von Süd nach Nord. Brockaux: Leipzig, Germany.

Wang, K., Goldstein, S., Bleasdale, M., Clist, B., Bostoen, K., Bakwa-Lufu, P., Buck, L.T., Crowther A., Dème, A., Mcintosh, R.J., Mercader, J., Ogola, C., Power, R.C., Sawchuk, E., Robertshaw, P., Wilmsen, E.N., Petraglia, M., Ndiema, E., Manthi, F.K., Krause, J., Roberts, P., Boivin, N., and Schiffels, S. 2020. Ancient genomes reveal complex patterns of population movement, interaction and replacement in sub-Saharan Africa. Science Advances, 6(24): eaazo183.

Williams-Schmid, M.R. 2001. Keramikfürhende Befunde aus Mouanko-Lobethal, Province du Littoral, Kamerun. Unpublished MA Thesis. Eberhard-Karls-Universität: Tübingen, Germany.

Wotzka, H.-P. 1995. Studien zur Archäologie des zentralafrikanischen Zä̈re-Beckens und ihre Stellung im Kontext der Bantu-expansion, Africa Praehistorica. Heinrich-Barth Institut: Köln, Germany.

Wotzka, H.-P. 2019. Ecology and culture of millets in African rainforests. Ancient, historical, and present-day evidence. In: Eichhorn, B., and Höhn, A. (eds) Trees, grasses and crops. People and plants in sub-Saharan Africa and beyond, Frankfurter Archäologische Schriften $n^{\circ} 37$. Rudolf Habelt: Bonn, Germany, pp. 407-429. 